\title{
Proven and putative vectors of American cutaneous leishmaniasis in Brazil: aspects of their biology and vectorial competence
}

\author{
Elizabeth Ferreira Rangel ${ }^{1 /+}$, Ralph Lainson ${ }^{2}$ \\ 'Laboratório de Transmissores de Leishmanioses, Instituto Oswaldo Cruz-Fiocruz, Av. Brasil 4365, 21045-900 Rio de Janeiro, RJ, Brasil \\ ${ }^{2}$ Departamento de Parasitologia, Instituto Evandro Chagas, Secretaria de Vigilância em Saúde, Belém, PA, Brasil
}

The aim of the present review is to give relevant information on aspects of the biology and ecology, including the vectorial competence of Lutzomyia sand fly species suggested as vectors of American cutaneous leishmaniasis in Brazil. The disease, due to Leishmania (Viannia) braziliensis, has been registered in most municipalities in all the Brazilian states and its transmission is associated with more than one sand fly species in each geographical region. A variety of Leishmania species can be found in the Amazon basin, where different epidemiological chains have been detected with the participation of different phlebotomine vectors. Finally, a discussion is presented on some sand fly species found naturally infected by Leishmania, but for which there is as yet no evidence regarding their epidemiological importance.

Key words: American cutaneous leishmaniasis - Lutzomyia sand fly species - vectorial competence - Brazil

American cutaneous leishmaniasis (ACL) in Brazil is caused by a variety of dermotropic Leishmania species and the greatest diversity of these parasites is to be found in the Amazon Region.

Transmission of the causal agents involves different species of phlebotomine sand flies (Diptera: Psychodidae: Phlebotominae) in close relationship with the mammalian reservoir hosts of the parasites, with the consequent formation of a number of different transmission cycles throughout the country. The data from ecological and epidemiological studies on the different species of the subgenera Viannia and Leishmania, together with those from experimental laboratory transmissions, have either suggested or definitely indicated certain species of sand flies as being responsible for the transmission of ACL. Relatively few, however, have been considered as outstandingly important vectors.

According to the taxonomic criteria proposed by Young and Duncan (1994), three genera of sand flies are recognized in the New World: Lutzomyia França \& Parrot, 1924; Brumptomyia França \& Parrot, 1921 and Warileya Hertig, 1940. The genus Psychodopygus Mangabeira, 1941 has been accepted by some (Fraiha et al. 1971, Fraiha \& Ward 1974, Forattini 1973, Lainson et al. 1973) and modifications of the taxonomy have been suggested (Galati 2003). In this review, however, we propose to follow that of Young \& Duncan (1994).

Vectorial competence of some neotropical sand flies

Lutzomyia (Nyssomyia) intermedia (Lutz \& Neiva, 1912) - L intermedia, described from specimens collect-

Corresponding author: elizabethrangel@fiocruz.br

Received 4 September 2009

Accepted 19 October 2009 ed in the Fazenda Ouro Fino, in the state of Minas Gerais (MG), where it was found to be abundant in houses, was one of the first species of sand fly to be described in the Neotropical Region.

In the 1940's, important studies on the biology of L. intermedia s.l. were made by Barretto (1943) in the state of São Paulo (SP), together with observations on the behaviour of some other species of sand fly. It is a species found in both primary and secondary forests and particularly in areas where deforestation has gradually modified the ecological profile - clearly seen in those parts of the country that underwent past colonization. As long ago as 1943, Barretto suggested that L. intermedia s.l. had, in fact, developed a preference for secondary forest or low, bushy vegetation located in areas suffering from such human impact and according to Tolezano et al. (1980), the environmental changes that took place in SP at the beginning of the 20th century certainly modified the composition of the phlebotomine fauna. While this caused other species of silvatic sand fly to disappear, or survive at low frequency, L. intermedia s.l. adapted so well to the peridomestic habitat that it actually has become the predominate species of sand fly in a new epidemiological profile for ACL in this region. These authors further suggested that the small numbers of this sand fly now captured in the remaining forest indicates that transmission of ACL by L. intermedia is now taking place solely outside of that habitat.

Like most sand flies, L. intermedia s.l. commences its feeding activities at dusk and increases it most markedly during the first half of the night. It has been shown to be abundant inside houses (Lutz \& Neiva 1912, Forattini 1953), where it feeds avidly on man. It is also attracted to domestic animals such as dogs and equines, which may have cutaneous lesions due to Leishmania (V.) braziliensis and commonly infests their shelters (Forattini 1973, Forattini et al. 1976, Araújo Filho 1979, Rangel et al. 1986, Gomes \& Galati 1989). 
Studies in Mesquita, state of Rio de Janeiro (RJ), have resulted in the capture of L. intermedia on man and domestic or silvatic animals in a variety of habitats, including the interior of houses, areas approximately 180 $\mathrm{m}$ from the houses and in neighbouring forest about 800 $\mathrm{m}$ away (Rangel et al. 1999). To the authors, therefore, these findings suggested the existence of genetically heterogenous populations of this sand fly. Meneses et al. (2005), however, used three different molecular markers, MLEE, RAPD and PCR, to study the sand fly populations from three different ecotopes and concluded that they were genetically homogeneous. They suggested that the dispersion of $L$. intermedia to different habitats was merely a reflection of the domiciliation process: a similar variation of habitat has been observed in $\mathrm{RJ}$ foci of ACL (Souza et al. 2002). Investigating L. intermedia populations from regions with two distinct eco-epidemiologies of $L$. (V.) braziliensis in the state of Espirito Santo (ES), Souza-Rocha et al. (2007) suggested that in addition to the homogeneity estimated by gene flow $\left(F_{\mathrm{st}}\right)$ this sand fly forms different clusters according to microhabitat: the authors therefore suggested the presence of different transmission cycles of ACL.

With regard to seasonality, Forattini (1973) pointed out an irregular behaviour of the sand fly, which he considered to have a greater population density during the cold months of the year. In RJ, however, Rangel et al. (1990) found it to be present throughout the year, with maximum density in June, August and October, and later studies by Souza et al. (2003) showed that the L. intermedia population was at its maximum density in the hottest season of the year.

Just one year after, Sergent et al. (1921) had suggested that ACL in the Old World was transmitted by the bite of phlebotomine sand flies, the young scientist Henrique Aragão (1922) of the Instituto Oswaldo Cruz considered the possibility that these insects were also the vectors of the disease in the Americas. He pointed out the association of sand flies with the presence of human infection in Águas Férreas, near the hillsides of Corcovado and locality of Santa Teresa, city of Rio de Janeiro, and then indicated $L$. intermedia as a putative vector of $L$. $(V$.) braziliensis by producing an ulcer containing amastigotes on the nose of a dog inoculated with a triturated pool of L. intermedia that had fed on the lesions of persons with ACL.

Epidemiological data, accumulated over the years, have steadily increased the suspicion that this sand fly may be an important vector of ACL in many endemic areas of Southeastern Brazil, such as SP and RJ, although in MG and ES its presumed role would be shared with Lutzomyia (N.) whitmani, a proven vector (Falqueto 1995, Mayrink et al. 1979). More recently it has been suggested that it participates in the transmission of ACL in the region of Viçosa, MG (Santos et al. 2003) and in the Northeast of Brazil, in the state of Rio Grande do Norte (Ximenes et al. 2000). Souza et al. (2003) also noted the sympatric presence of $L$. intermedia and $L$. whitmani in an area of ACL in RJ and suggested that here, too, both species could be involved in the transmission of the disease: they pointed out that whereas $L$. intermedia predominated in the peridomestic habitat, $L$. whitmani was most frequent in banana plantations. Finally, since the studies of Barretto (1943), the presence of $L$. intermedia s.l. has been indicated in four different municipalities of SP that are considered to be areas of high ACL endemicity.

After the 1970's, the incidence of this disease increased in SP, with an impressive concentration of cases in the Vale do Ribeira, where studies on the sand fly fauna suggested L. intermedia s.l. as the vector of the parasite. Changes in the vegetation are presumably the reason for the resulting predominance of $L$. intermedia in this populated environment. Recent investigations in the same area have since shown that this sand fly represented almost $100 \%$ of captures made in the domestic environment, indicating the very close contact this insect has with man (de Castro et al. 2005). Souza et al. (2005) have emphasized the tendency of L. intermedia to bite man in a variety of habitats throughout RJ.

In 1952, Forattini and Santos worked in an area of ACL transmission in the state of Paraná (PR) and noted promastigotes (referred to as leptomonads) in L. intermedia s.l.: they were very like those seen by Aragão (1922). Later on, Forattini et al. (1972) recorded a similar infection, which they attributed to a species of Leishmania, in a specimen of this sand fly from SP. Circumstantial evidence indicating the vectorial competence of $L$. intermedia s.l. was obtained when a campaign of DDT application in an area of ACL transmission in RJ resulted in abrupt reduction in the population of $L$. intermedia s.l. and a drop in the number of cases of the disease (Guimarães \& Bustamante 1954, Guimarães 1955). In addition, during an epidemic of ACL in the locality of Jacarepaguá, city of Rio de Janeiro, in 1974, $92.7 \%$ of 47,761 sand flies captured were $L$. intermedia (Fiocruz Technical Report), while entomological studies during an outbreak of ACL on Ilha Grande, RJ, showed a prevalence of this species of sand fly (Araújo Filho 1979). These observations and the succession of reports on the combined presence of $L$. intermedia s.l. and cases of ACL in several foci of the disease in SP and RJ have all centred attention on this sand fly as the most likely vector (Forattini 1953, Forattini et al. 1976, Araújo Filho 1979, Gomes et al. 1986, Rangel et al. 1986, 1990).

More definite support for the incrimination of $L$. intermedia came when Rangel et al. (1984) captured an infected specimen in the Jacarepaguá focus of ACL. The parasite showed attachment of the promastigotes to the wall of the hindgut (pylorus), characteristic of species of the subgenus Viannia and intradermal inoculation of the contents of the gut into the feet of hamsters produced nodular lesions containing amastigotes. Although the parasite was not characterized to species level by the current modern methods, these findings and the fact that the infected san dfly was from an area of active transmission of $L$. (V.) braziliensis makes it highly likely that it was, in fact, this species. Studies on the development of $L$. (V.) braziliensis in experimentally infected $L$. intermedia have added further evidence (Rangel et al. 1992). In addition to the development of the parasite in the pylorus, free promastigotes were shown to migrate to the 
foregut and infect the stomodeal valve. A further link in the chain of evidence incriminating $L$. intermedia as a vector of ACL came with the isolation of a parasite from a specimen of this sand fly, captured in the Jacarepaguá focus of the disease and identified as $L$. (V.) braziliensis (Pita-Pereira et al. 2005). This certainly reinforced all the ecological and epidemiological evidence slowly built up over the past years and, in particular, supports the view that the infection in the wild-caught $L$. intermedia found by Rangel et al. (1984) was also this parasite.

During the early studies on L. intermedia, there was very little information available regarding the possible mammalian source of infection for this sand fly although from the insect's original habitat in forested areas, it was clearly from silvatic animals and a number of reports on the isolation of Leishmania from rodents in localities highly endemic for $L$. (V.) braziliensis put these animals high on the suspect list (see in the discussion on Lutzomyia wellcomei).

In more recent times, following the adaption of $L$. intermedia to the peridomestic habitat, the frequent finding of dogs and equines with cutaneous lesions due to $L$. (V.) braziliensis led to the conclusion that the severe deforestation in these areas had resulted in migration of infected wild animals (particularly rodents) to residential areas, the infection of $L$. intermedia in this new habitat and, finally, transmission of $L$. ( V.) braziliensis to the domestic animals. These, it has been suggested, may now serve as a further source of infection for the sand flies and the creation of a new, extra-silvatic transmission of human ACL. The observation that sloths (Bradypus variegatus) from neighbouring forest frequently visit residential areas in the municipality of Mesquita, RJ, raised the question as to whether this animal might also be a source of infection (Pirmez et al. 1997). In the same area, recent use of the precipitin test on engorged sand flies from the interior of houses and the peridomestic habitat have indicated that the population of $L$. intermedia there feeds on man and on domestic animals such as birds, dogs, equines and rodents (Afonso et al. 2005). Clearly, conclusive evidence is needed to show that domestic animals with cutaneous lesions can serve as a source of infection for the sand fly and, most importantly, to show that amastigotes are available in apparently normal skin, in addition to the very limited area of infected tissue at the border of a lesion.

Lutzomyia (Nyssomyia) neivai (Pinto, 1926) - This sand fly was described from a male specimen collected in a house in the grounds of the Instituto Butantan, city of São Paulo. Later, Pinto placed it in synonymy with $L$. intermedia, a taxonomic position that was accepted by most sand fly specialists. In 1996, however, Marcondes made a study of the morphology of males and females collected in the locality of Fortim Campero, Tarija, Bolivia and compared morphology of the holotype male with other males from this area. He considered that the females of $L$. neivai and $L$. intermedia could be differentiated on morphology of the spermathecae (differences in the common duct), the number of teeth of the ciborium and wing venation. In addition, the males could be separated on wing venation and the morphometry of the ejaculator bomb and genital filament. Still other differences have since been reported (Marcondes et al. 1997, Andrade-Filho et al. 2004).

Regarding the possible participation of L. neivai in the transmission of ACL, Marcondes et al. (1997) suggested the possibility of this in the Southeast of Brazil, in the colder and dryer areas.

Studies on the sand fly fauna in 37 municipalities in PR showed that L. neivai represented $75.6 \%$ of all the specimens collected and distribution of this species in areas of ACL transmission strengthened the suggestion that it may be another vector of the disease (Silva et al. 2008).

Recently, the General Office of Health in Porto Alegre, state of Rio Grande do Sul (RS), registered its first autochthonous case ACL due to $L$. $(V)$ braziliensis and, in the locality of Pitinga, capture of sand flies around the house of an ACL case showed that $94.9 \%$ were L. neivai and that L. intermedia was not present (ACR Azevedo et al., unpublished observations). Recent investigations in Southeastern Brazil suggest that migration of $L$. neivai from forest to residential areas have resulted in the appearance of ACL cases. Studies on the feeding preferences of this sand fly among domestic animals (pig, dog, rabbit and chicken) showed it to be an opportunistic feeder with little host preference (Dias-Sversutti et al. 2007). Stronger evidence supporting the suggestion that it is an important vector of ACL, in certain areas, was provided by a study which reported positive results of tests on sand flies using PCR multiplex coupled to non-isotopic hybridization, suggesting infection with $L$. $(V$.) braziliensis. The specimens tested were from an endemic area of ACL in Porto Alegre, RS (Pita-Pereira et al. 2009). Additionally, Marcondes et al. (2009, unpublished observations) reported the natural infection of $L$. neivai by a Leishmania sp., of the subgenus Viannia in a focus of ACL in the state of Santa Catarina. In a study of the biology of this sand fly in an endemic area in SP, however, Casanova et al. (2009) considered that it has low competence as a vector of Leishmania.

To complete the incrimination of this sand fly as another vector of this parasite, all that is now needed is its actual isolation and characterization from undoubted L. neivai and, if possible, its experimental laboratory transmission by this sand fly.

L. whitmani (Antunes \& Coutinho, 1939) - In 1939, Antunes and Coutinho described a new sand fly species which they named Flebotomus whitmani in honour of Dr. Whitman, of the Rockefeller Foundation, who was collaborating with the Brazilian government in attempts to control yellow fever. Males and females were described from specimens collected in Ilhéus, state of Bahia (BA). Before this the new species had often been mistaken for $L$. intermedia.

Early information on the biology of L. whitmani was given by Barretto (1943) in his entomological studies in SP. It was considered to be a silvatic species, although it could be found inside houses that were situated within or near the forest. At dusk it was found biting man, in addition to feeding on dogs and was shown to be present in large numbers in chicken houses. As the localities 
Barretto studied were close to deforested areas, he suggested that the high population density under these circumstances was simply due to the wide variety of blood sources available to this sand fly.

In 1953, Forattini confirmed the presence of $L$. whitmani in both the forest and nearby domestic animal shelters in SP. Later (1960), he commented on the fact that although inicially dependant on primary forest, this sand fly could now be captured, during several months of the year, inside houses, peridomestic pigsties and banana plantations and there was no doubt that it was now thriving in a domestic environment. In the same publication, Forattini (1953) was of the opinion that although there were reports indicating that $L$. whitmani coexists with $L$. intermedia in areas recently occupied by man and may actually outnumber the latter species as the environmental alterations procede, more detailed information was needed to confirm this suggestion.

In RJ in general, the L. whitmani population has for some time remained at low level (Rangel et al. 1986, 1990, Oliveira et al. 1995). Souza et al. (2001) registered this sand fly's presence in the Atlantic Forest and, more importantly, its frequency in residential areas close to the forest. The same authors recorded both $L$. intermedia and $L$. whitmani biting man in the peridomestic habitat close to forest and noted that the former prevailed in the residential area while the latter was the most frequent of the two insects in the forest. They observed a higher density of $L$. whitmani in the winter months, while $L$. intermedia was most abundant in the hotter months of the year (Souza et al. 2002).

The tendency of $L$. whitmani to occupy residential areas in MG was discussed by Mayrink et al. (1979) and Passos et al. (1991). It was found feeding on man and domestic animals and thought to possibly be breeding in this habitat. Conversely, it was found in very small numbers in the neighbouring forest.

In Northeast Brazil, in BA and CE, its behaviour has been shown to be similar to that seen in the Southeastern Region: namely, highly attracted to man and well adapted to the domiciliary habitat (Barreto et al. 1982, Vexenat et al. 1986). In BA, it was suggested that L. whitmani might be breeding in the cocoa plantations (França et al. 1991).

Regarding seasonality, differences in behaviour have been noted in different regions of Brazil, probably due to differing climatic conditions. In the Southern Region, for example, Barretto (1943) noted its presence at all months of the year, while in studies in Petrópolis, RJ, it was found in greater numbers during the months of low temperature in June, July and August (Souza et al. 2002).

Although the dusk and nocturnal feeding habit of $L$. whitmani follows the usual sand fly pattern (Barretto 1943) it, too, has been shown to be somewhat variable in different regions of Brazil. In the Northeast, Azevedo and Rangel (1991) showed that it can also be captured during the whole of the dawn period, in chicken houses or feeding on equines, with maximum activity from 1-3 am. Souza et al. (2004) noted that in RJ it could be found feeding on man, in the peridomestic habitat, between
4-6 am and such behaviour was previously recorded by Teodoro et al. (1993) in PR; studies on host preferences of $L$. whitmani among domestic animals, made in the same state, showed that this insect is an opportunistic feeder, resulting in a wide choice of hosts in the peridomestic environments of human colonization.

In primary forest, in several different regions of PA, Lainson et al. (1979) noted that L. whitmani s.l. has very different habits from those discussed above, in other regions. It was found to be essentially silvatic and was captured principally from the large tree-trunks and in the forest canopy. It was disinclined to bite man and attempts to demonstrate its invasion of houses located very near the forest were completely unsuccessful. Subsequent studies confirmed these observations and led to the conclusion that any divergence from this behaviour is likely to occur only under special conditions (Ready et al. 1986, Lainson 1988, Shaw et al. 1991).

This situation led to the suggestion that $L$. whitmani s.l. might represent a species complex of two or more taxa (Lainson 1988) and has resulted in several comparative studies on populations of this sand fly from widely different areas of Brazil. Some investigations suggested the existence of at least three different lineages of this sand fly, based on biological characters, geographical variations and morphometric features, together with observations on sequences of mitochondrial DNA (Rangel et al. 1996, Ready et al. 1997, 1998). Rangel et al. (1996) made it clear, however, that they did not discard the possibility that the populations they studied, from PA, CE and BA could represent a cline. Ishikawa et al. (1999) studied populations from the North, Northeast, Southeast and the South Regions and indicated the existence of a clade from Rondônia (RO) within the lineage of forested areas, which included haplotypes of the Amazon and Atlantic Forests and Ilhéus (the type locality of L. whitmani). They suggested that their findings did not sustain the hypothesis of a cryptic species complex, but rather the occurrence of a recent crossing over of populations in forested areas.

Margonari et al. (2004) studied populations of $L$. whitmani from the Northeast and the Southeast of Brazil. They confirmed observations on the similar morphometry of these, but presented evidence of two biogeographical "clusters". Latterly, however, they suggested the existence of a genetic flow between the two lineages.

Finally, Campbell-Lendrum et al. (1999) maintained that they could observe no significant difference in the anthropophilia of L. whitmani s.l. from North Brazil and L. whitmani sensu stricto from other areas in Brazil: a finding not supported by some 40 years of entomological observations, in an extensive area of primary forest in PA, by workers in the Instituto Evandro Chagas.

Regarding the incrimination of L. whitmani as an important vector of ACL, the first suggestion of this was in 1941, when Pessôa and Coutinho found a specimen from SP infected by flagellates which were considered to possibly be promastigotes of Leishmania: as a result, entomological investigations were intensified in areas of ACL transmission in this region and soon showed that although considered as a silvatic species, $L$. whitmani was a highly anthropophilic sand fly with a particularly dense population (Barretto 1943, Forattini 1954). 
In Southeastern Brazil, data in the literature suggest the participation of this sand fly in the transmission of ACL in a focus of the disease in Caratinga, MG and in the mountainous area of Afonso Cláudio (Mayrink et al. 1979, Falqueto 1995), and Souza et al. (2002) considered that it might be sharing the role of a vector of $L$. (V.) braziliensis, together with $L$. intermedia, in rural RJ. Recently, the finding of a specimen of L. whitmani infected with a Leishmania of the subgenus Viannia by PCR analysis, in a region very close to Belo Horizonte, $\mathrm{MG}$, has led to the suggestion that this sand fly could be the vector of cutaneous leishmaniasis in that area (Carvalho et al. 2008).

In the South, L. whitmani was also considered as a possible vector of ACL in PR, while in the northern part of this state a natural infection with $L$. (V.) braziliensis found in one specimen and the insect's high population density clearly emphasized this sand fly's medical importance (Luz et al. 2000, Teodoro et al. 2003).

In all areas of ACL in Northeast Brazil, this same species of sand fly is considered as an important vector of the disease, based on the the finding of specimens infected by L. (V.) braziliensis in the area of Três Bracos, BA (Hoch et al. 1986, Ryan et al. 1990). The sand fly's predominance in houses and the peridomestic habitat in general prompted these authors to suggest the development of a purely domestic cycle of transmission by $L$. whitmani. In Ilhéus, BA, the type locality of this sand fly, its fondnest for human blood and high population density in the domestic habitat led to the same conclusion (Azevedo \& Rangel 1991). In the Serra de Baturité, CE, a parasite of the subgenus Viannia and others positively identified as $L$. (V.) braziliensis were found in dissected L. whitmani (Azevedo et al. 1990, Queiróz et al. 1994) and, once again, these findings together with population density in the peridomestic habitat indicated this fly as the local vector of ACL due to this parasite. Gil et al. (2003) registered L. whitmani as the second most prolific sand fly in captures made in the central area of RO, stressed its preferential arboreal habits and recorded the presence of unidentified trypanosomatid parasites in some specimens.

In the municipalities of Rio Branco, Bujari and Xapuri, in the state of Acre (AC), a study of the sand fly fauna and potential vectors of ACL showed that $L$. whitmani was the most abundant species, with its spatial distribution coinciding with proven transmission sites of L. (V.) braziliensis: it was therefore suggested that this sand fly was a probable vector of this parasite in that region (Azevedo et al. 2008).

The state of Tocantins (TO) has suffered environmental impacts resulting in ecological changes, due to the construction of hydroelectric plants, agricultural activities and the establishment of new settlement areas, and the increasingly high incidence of ACL in this region has probably been due to these activities. L. whitmani is found in most of the endemic municipalities, especially in the areas that have been degraded by man (Vilela et al. 2008). In the Central-Western Region, some studies conducted in areas that suffered environmental changes due to human activities have suggested $L$. whitmani as an important vector of $L$. (V.) braziliensis (Galati et al. 1996, Dorval et al. 2009).

Nowadays, this sand fly is suggested to be the most important vector of ACL in Brazil, having been recorded in a large number of endemic areas (Costa et al. 2007) and in association with wide vegetation diversity. The aforesaid alterations in ecology, together with climatic changes, most probably account for the spread of ACL in Brazil in recent years (Shaw 2007) and, in this respect, L. whitmani appears to be a sand fly which readily adapts to new environments, such as degraded areas, in association with domestic animals and man in rural and periurban areas (Costa et al. 2007, Shaw 2008). Using analyses by ecological niche modeling in a study on the ecological distribution of ACL vectors, Peterson and Shaw (2003) predicted that with climatic changes, L. whitmani will continue to adapt to new conditions and possibly spread its distribution in Brazil even further.

The very different behaviour of L. whitmani s.l. in primary forest in PA, North Brazil has already been discussed and, till now, this sand fly has not been associated with ACL due to $L$. (V.) braziliensis in this region. The suggestion was made, however, that promastigotes of a member of the subgenus Viannia found in this sand fly in Monte Dourado, PA an area of ACL due to Leishmania (Viannia) guyanensis, were probably those of this parasite and that $L$. whitmani s.l. was participating in its transmission together with the principal vector Lutzomyia umbratilis (Lainson et al. 1981b). The parasite was not isolated for characterization, however and in view of the later isolation and identification of Leishmania ( $\mathrm{Vi}$ annia) shawi from L. whitmani s.l. in another area of primary forest in PA (Lainson et al. 1989) it remains possible that the parasite of L. whitmani in Monte Dourado, PA was also L. (V.) shawi (Rangel et al. 1996, Lainson \& Shaw 1998). Considering the frequency of human infection with $L$. (V.) shawi and the reluctance of $L$. whitmani s.l. to feed on man in the Amazon Region, one is left to the conclusion that there must be a much more anthropophilic sand fly involved in the transmission of $L$. (V.) shawi, with L. whitmani s.l. merely maintaining the enzootic in wild animals.

L. (Nyssomyia) umbratilis Ward \& Fraiha, 1977 During a study of the epidemiology of cutaneous leishmaniasis in Surinam, in 1966, Wijers and Linger recorded flagellate infections in a tree-trunk inhabiting sand fly which they referred to as $L$. anduzei. It was thought to be the most likely vector of "bosch yaws", or pianbois, due to $L$. (V.) guyanensis, but their attempts to infect hamsters with the flagellates failed and the parasite remained unidentified.

Lainson et al. (1976) worked in the primary forest of Monte Dourado (Jari), PA, Brazil, north of the Amazonas River, where approximately 300 cases of ACL due to $L$. $(V$.) guyanensis were recorded, in one year, in men working on deforestation. They recorded massive infections with $L$. $(V$.$) guyanensis in four of 55$ specimens of a sand fly considered, at the time, to be Lutzomyia an- 
duzei and isolated the parasite following the intradermal inoculation of hamsters. Suspicions were aroused during these studies, however, that the vector was not in fact $L$. anduzei and subsequent morphological studies showed that it was a closely related and morphologically very similar sand fly which was new to science.

Ward and Fraiha (1977) described the new sand fly as L. umbratilis from 10 females collected during the work in Monte Dourado, PA and an intense study of its behaviour was iniciated in the same area (Lainson et al. 1979). It was found that although sand fly species of the subgenus Psychodopygus predominated at ground level, $L$. umbratilis was extremely abundant in the forest canopy, but descended to ground level, presumably to oviposit, by way of the tree-trunks, on which it could be collected in great numbers in the early morning. In studies conducted in RO, in the area of Samuel Ecological Station, however, it was noted that $L$. umbratilis predominated in the canopy (Azevedo et al. 1993). In Monte Dourado, PA it was noted that L. umbratilis flies off the tree-trunks when disturbed by man's activities and attacks the nearest person. In the same study, $L$. (V.) guyanensis was isolated from 16 more specimens of L. umbratilis and, of 77 sand flies attacking two men collecting from the tree-trunks, 72 (92.5\%) proved to be L. umbratilis. Some idea of the efficiency of this sand fly in the transmission of ACL in the Monte Dourado, PA area may be gained by the fact that the two men developed a total of 13 leishmanial lesions due to $L$. (V.) guyanensis on their arms, probably providing the most conclusive incrimination of a vector of ACL ever obtained!

The explanation of this great number of infected sand flies on the tree-trunks came with the detection of $L$. $(V$.) guyanensis in 27 of 59 specimens of the sloth Choloepus didactylus in the Monte Dourado area, PA (Lainson et al. 1981a, b). This animal spends most of its time in the forest canopy and has thus become the principal mammalian reservoir host of the parasite. As the animal may remain in the same tree for a considerable time there is a gradual build-up of infected L. umbratilis on a given tree. This sand fly's similar role as a vector of $L$. (V.) guyanensis and its common presence in the forest canopy and on large tree-trunks at ground level has been recorded in some other areas of the Amazon Region of Brazil (Arias \& Freitas 1977a, 1978) and in French Guiana (Le Pont $\&$ Pajot 1980). Infection of an undoubted specimen of $L$. anduzei with a parasite having development consistent with that of members of the subgenus Viannia has been reported in Manaus, state of Amazonas (AM) (Arias \& Freitas 1977b). However, this sand fly can, at most, now be considered only as a possible secondary vector of $L$. $(V$.) guyanensis and is probably of low importance with regards transmission of ACL to man.

Ready et al. (1986) made a detailed study of the ecology of L. umbratilis in the region of Monte Dourado, PA. It is highly anthropophilic and presumably becomes infected after feeding at night, particularly on sloths, but also on other arboreal animals such as the ant-eater $T a$ mandua tetradactyla. In Manaus, AM, precipitin tests on blood in naturally fed L. umbratilis showed that $66 \%$ of them had fed on sloths (Christensen et al. 1982). In addition to its nocturnal feeding habits, however, this sand fly clearly will feed in the early daylight hours if disturbed from its resting place on tree-trunks. It is recorded biting man in the dry season and, particularly, directly after the rainy season.

Areas of high ACL prevalence due to L. (V.) guyanensis may be found in communities located in or very close to primary forest and this has led to the erroneous impression that $L$. umbratilis is undergoing the process of adapting to a peridomestic habitat. There are no consistent data that this is so, however and any transmission in this environment is almost certainly due to sand flies that have been attracted to a residential area, from nearby primary forest, by the lights of the houses. Esterre et al. (1986) discussed the acquisition of ACL due to $L$. (V.) guyanensis in persons living in a small village within forest in French Guyana and came to the same conclusion: when the forest was cleared to about 400-500 m around the village, all peridomestic transmission ceased. Guerra et al. (2007) discussed this situation in Manaus, AM, and were clearly of the opinion that the eco-epidemiology of ACL there is the same as that recorded in Monte Dourado, PA. In other forested areas on the outskirts of Manaus, however, L. umbratilis was considered to be present in equal numbers in both the forest and in the peridomestic habitat (Barbosa et al. 2008).

There are observations suggesting that $L$. umbratilis is a vector of $L$. $(V$.) guyanensis in the state of Bolivar, Venezuela (Feliciangeli et al. 1985), possibly indicating an expansion of the Brazilian zoonotic cycle.

Rangel et al. (1998) isolated L. (V.) braziliensis from patients with ACL in Peixoto de Azevedo, state of Mato Grosso (MT) and Azevedo et al. (2002) noted that one of the most abundant and highly anthropophilic sand fly in the same area was, morphologically, L. umbratilis. In addition, they confirmed observations made by workers in the Instituto Evandro Chagas, Belém, PA (Ward et al., personal communication) that the population of this sand fly south of the Amazonas River, behaved very differently from that studied north of the river (Monte Dourado, PA). Although abundant in the forest canopy, it was not found to accumulate on the tree-trunks at ground level. It was this marked behavioural difference that led Lainson (1988) to suggest that perhaps the populations of $L$. umbratilis north and south of the Amazonas River were not identical and, since that time, the taxonomic status of L. umbratilis started to attract special attention.

Azevedo et al. (2002) studied the morphology and the morphometric characters of the head, thorax and abdomen of populations of the insect from Brazil [states of Amapá (AP), PA, AM and MT] and Venezuela (state of Bolivar). They found that analysis of morphological characters could not separate the populations, but that the quantitative characters (morphometry) showed 77\% of these separated the Venezuelan population from the Brazilian ones. The analysis did not, however, supply evidence of heterogeneity among the populations from Brazil, but recent studies on L. umbratilis populations from Brazil and Venezuela have suggested the existence 
of three different populations which are separated by the geographical barriers of the planalto of state of Roraima (RR) and the two rivers, Negro and Amazonas; one is in Venezuela and the other two in Brazil (north and south of the Amazonas River (Azevedo 2008).

The same author recorded 52 different species of sand flies in the municipalities of Rio Branco, Xapuri and Bujari, AC (17 being new records for that state); L. umbratilis was very abundant in the forest canopy, in close association with the major reservoir of $L$. $(V$. guyanensis, the sloth $C$. didactylus. Tojal da Silva et al. (2006) recorded the presence of ACL due to $L$. (V.) guyanensis in the municipality of Rio Branco, leading Azevedo et al. $(2005,2008)$ to conclude there is, in fact, a transmission cycle of this parasite south of the Amazonas River, involving L. umbratilis.

Although the markedly different behaviour of the populations north and south of this river remains to be explained, it does help to account for the very low incidence of ACL due to $L$. (V.) guyanensis throughout PA south of the river compared with the alarmingly high number of cases north of it: the failure of infected L. umbratilis of the southern population to concentrate on tree-trunks at ground level will greatly reduce its contact with man. ACL south of Amazonas River is mostly caused by $L$. (V.) braziliensis transmitted by sand flies which are, predominately, not arboreal and it is of particular interest that an isolation of a Leishmania from L. umbratilis s.l. captured in Peixoto de Azevedo, MT, proved to be $L$. (V.) braziliensis and not L. (V.) guyanensis (Azevedo et al. 2002), raising the question as to whether or not some arboreal animals may be hosts of $L$. (V.) braziliensis.

Lutzomyia (Nyssomyia) flaviscutellata (Mangabeira, 1942) - In their various field trips in Brazil, Mangabeira and his collaborators captured approximately 17 thousand specimens of sand flies, representing 57 different species and with 35 of them being new to science. Among the latter was Mangabeira's description of $L$. flaviscutellata, based only on the male insects and collected in the locality of Aurá, close to Belém, PA. Later, Sherlock and Carneiro (1962) described the female of the species following the establishment of a laboratory colony of this sand fly from BA. It must be stressed, however, that the taxonomic status of the material from BA has been questioned (Young \& Duncan 1994). The specific name of this sand fly was probably chosen in view of the double colouration of the shield, where the scutelo is clear and the remainder of the structure a dark brown (Latin fla$v u s=$ golden; yellow $+s c u t u=$ shield) .

L. flaviscutellata has a wide geographical distribution and can be found in very different habitats, such as primary forest, secondary or copse-like vegetation and lowland várzea forest which, during half of the year, is subject to various degrees of flooding. Ready et al. (1983) showed that, together with the various rodents and marsupials on which it feeds, it rapidly adapts to plantations of introduced trees such as Pinus and Gmelina and it is occasionally captured in the peridomestic habitat of houses located near forest (Lainson et al. 1994). With the continuous environmental and climatic changes, there are modifications in the behaviour of some sand fly vectors of leishmaniasis and in the Brazilian cerrado of Central Brazil (extensive, flat areas of low, fire-resistant trees, small palms and thorny bushes) it is possible to note the spread of L. flaviscutellata, found in association with domestic animal shelters and the presence of new cases of anergic diffuse cutaneous leishmaniasis (ADCL) (Vilela et al. 2008, Shaw 2008).

L. flaviscutellata is a low-flying sand fly, essentially nocturnal in its biting habits, highly attracted to rodents, but not greatly attracted to man (Lainson \& Shaw 1968, Shaw \& Lainson 1968, Shaw et al. 1972, Gomes 1994, Vilela et al. 2006, 2007). This is fortunate, as it is the proven vector of Leishmania (Leishmania) amazonensis which, in addition to being an agent of single-lesion cutaneous leishmaniasis, is also the cause of ADCL in individuals with a faulty immunological system. ADCL is highly disfiguring and cured with difficulty.

In 1963, Lainson paid a visit to the Instituto Evandro Chagas in Belém, PA and, during a demonstration of the animal trapping programme of the Rockefeller Virus Laboratory, discussed the unique opportunity this held for the examination of these animals for evidence of Leishmania infections: ACL was a considerable public health problem in Amazon Region of Brazil. The Director of the programme, the late Dr. Otis Causey, was impressed with the similarity of cutaneous lesions he had seen on the tails of wild rodents and those caused by Leishmania (Leishmania) mexicana on the tails of forest rodents in Belize, Central America (Lainson \& Strangways-Dixon 1964). He promised to look more closely at the next ones he saw and within a few days presented Lainson with a stained smear of a lesion on the tail of the rodent Oryzomys capito, rich in amastigotes. At first it was thought that the parasite was L. (V.) braziliensis (Guimarães \& Costa 1966), but following subsequent study of the parasite it was given the name of Leishmania mexicana amazonensis (Lainson \& Shaw 1972) later amended to Leishmania (Leishmania) amazonensis (Lainson \& Shaw 1987).

With the knowledge that rodents were important reservoir hosts of the parasite, rodent-baited Disney traps were used to capture sand flies attracted to them. By far the greatest number trapped were L. flaviscutellata and dissection of these revealed eight out of 2,706 to be heavily infected with promastigotes, proved to be those of $L$. (L.) amazonensis (Lainson \& Shaw 1968): during this and continuing studies a total of 45 heavily infected $L$. flaviscutellata were recorded in 7,498 females dissected and on no occasion was the parasite encountered in other species of sand flies from the same area.

Finally, L. (L.) amazonensis was experimentally transmitted from hamster to hamster by the bite of $L$. flaviscutellata (Ward et al. 1977).

Lutzomyia (Nyssomyia) antunesi (Coutinho, 1939) This sand fly was first described from male specimens from Manacapuru, AM and examples were deposited in the University of São Paulo. The female was described by Floch and Abonnenc (1944), under the synonym of 
Phlebotomus machicouensis, from material collected in Machicou, French Guiana. The sand fly has its major concentration in the Amazon Region: the females are highly anthropophilic, low-flying and, like most sand fly species, feed at night.

While working in an area of visceral leishmaniasis on the island of Marajó, PA, Ryan et al. (1984) captured a small number of $L$. antunesi together with the catch of Lutzomyia longipalpis and three of them had promastigote infections. Intradermal inoculation of these into hamsters did not produce cutaneous lesions and the authors wondered if perhaps the parasites were Leishmania (Leishmania) infantum chagasi and that L. antunesi was functioning as a secondary vector of this parasite. However, no supportive evidence that this might be so has been forthcoming.

Silveira et al. (2002) described a small outbreak of ACL among soldiers carrying out manoeuvres in degraded primary forest in Belém, PA and a woman living very close to the same forest. The parasite differed from all other known Leishmania species in the Amazon Region of Brazil and was given the name of Leishmania (Viannia) lindenbergi in honour of Adolfo Lindenberg who first registered the existence of human ACL in Brazil (úlcera de Bauru), in SP in 1909. Nightime capture of sand flies attacking man was made and $50.7 \%$ of the captured specimens proved to be $L$. antunesi, which were taken principally when biting legs and feet. Apart from the large number attacking man, suspicion that the vector might be $L$. antunesi was increased by information that the soldiers had spent most of the time in trenches. This resulted in their arms and head being at ground level and it was precisely on these parts of the body that the lesions occurred. It remains to be seen, however, if $L$. antunesi is, in fact, the vector.

This species has been recorded in forest in TO, particularly in dense forest in the municipality of Guaraí, where the population density was very high (Vilela et al. 2006, 2007).

Lutzomyia migonei (França, 1920) - Data in the literature suggests that $L$. migonei should be regarded as a silvatic species, as it is found in both primary forest and, in lesser abundance, in secondary growth. It is, however, also commonly found inside houses and domestic animal shelters (Barretto 1943, Forattini 1973, Araújo Filho 1979, Rangel et al. 1986). The studies of Araújo Filho (1979) indicated that the highest population density of this sand fly was, in fact, in the peridomestic and domestic habitats.

Like L. intermedia, L. migonei is one of those primordially silvatic sand flies that has managed to survive the drastic ecological upheavels following deforestation for agriculture or other necessities. Whilst adapting to the new peridomestic and domestic habitats, it probably still helps to maintain the enzootic cycle of Leishmania in surviving secondary vegetation. It is notably anthropophilic, can also be found feeding on domestic animals such as dogs, chicken and equines and has retained its attraction to wild animals, as shown by its collection using armadillos as bait (Barretto 1943, Forattini 1973, Araújo Filho 1979, Rangel et al. 1986,
1994). Its feeding habits follow those of most other sand flies, commencing at dusk and increasing during the night: using humans as bait it has been possible to show that feeding activity slowly decreases in the more advanced hours, although feeding on a dog increased in the later hours of the night (Barretto 1943, Forattini 1973, Araújo Filho 1979, Azevedo \& Rangel 1991). Regarding its seasonality, L. migonei is not found at every month of the year, being absent in the dry and colder months (Barretto 1943, Forattini 1973).

The role of this sand fly in the transmission of ACL due to $L$. (V.) braziliensis was initially associated with foci of the disease in the Southeastern Region of Brazil, but now seems to have extended to the Northeastern Region: it is, however, only considered as a secondary vector. The first evidence suggesting the insect's medical importance was in the 1940's, when a specimen of L. migonei was found naturally infected by leptomonad flagellates (probably promastigotes of Leishmania) in SP (Pessôa \& Coutinho 1941); and in 1943 Barretto recorded this sand fly in zones of both high and low ACL endemicity in the same region. Recent studies by Camargo-Neves et al. (2002) (again in SP) renewed interest in L. migonei as a vector of ACL by recording an increase in the number of ACL cases which coincided with an increase in the population of this insect. The authors also commented on this sand fly's zoophilic and anthropophilic biting habits.

On Ilha Grande, RJ, Araújo Filho (1979) found a coincidental distribution of $L$. migonei and houses where human cases of ACL had been recorded or where individuals had positive Montenegro skin tests. It was suggested that this sand fly might be sharing the role of vector of $L$. (V.) braziliensis with L. intermedia. In another area of ACL, in Jacarepaguá, where L. migonei occurs in high density and is considered as a predominant species, this sand fly has shown a preference to feed on dogs, suggesting that this sand fly might simply be maintaining canine cutaneous leishmaniasis due to this parasite (Rangel et al. 1986). This, it was argued, might also have been the case on Ilha Grande. In contrast, L. migonei was found to represent only $15.8 \%$ of the local sand fly fauna captured in an area of ACL in Mesquita, RJ and presumably plays a minor role in transmission (Rangel et al. 1990). It was found in an agricultural area, close to Petrópolis, RJ, where human cases of ACL and canine infections have been recorded (Souza et al. 2002) and the same authors (2001) recorded its presence in the Biological Reservation Forest of Poço das Antas, RJ.

In Southeastern Brazil, Ferreira et al. (2001) indicated the high population density and anthropophilic habit of L. migonei in the town of Afonso Claudio, an area of ACL transmission in ES, where the insect was suggested to be a secondary vector. Alexander et al. (2002) have registered the presence of the sand fly in coffee plantations in MG, where cases of ACL were appearing.

In the Northeast Region, L. migonei has been shown to invade human dwelling places, especially in the rainy season; it was found feeding on equines and also biting man, although with less voracity (Azevedo \& Rangel 1991, Queiroz et al. 1994). In some localities it represent- 
ed $50 \%$ or more of captured sand flies. In a focus of ACL in Baturite, state of Ceará (CE), it was found infected with flagellates with a pyloric development typical of a Leishmania of the subgenus Viannia (Azevedo \& Rangel 1991). On this occasion the parasite was not isolated and identified, but a further infection of $L$. migone $i$ was found and this time the organism was isolated and characterized as $L$. (V.) braziliensis (Queiroz et al. 1994): due to the low attraction of L. migonei to man recorded by the authors in that area, however, it was suggested to be only a secondary vector of ACL.

In the town of Campo Grande, state of Mato Grosso do Sul (MS), L. migonei was recorded in an urban area by Oliveira et al. (2003) and more recently a specimen infected with $L$. (V.) braziliensis was captured in Jacarepaguá, RJ, where human and canine case of ACL have been reported (Pita-Pereira et al. 2005).

Lutzomyia (Pintomyia) fischeri (Pinto, 1926) - This species was described by Pinto following a study of sand flies captured around the city of São Paulo and Barretto (1943) registered its occurrence in 41 different municipalities of SP, in secondary forest. As it was most frequent where houses and animal shelters were localized nearby, it was suggested that this sand fly was in the process of adapting to the domiciliary environment. Forattini (1953) also noted this occurrence of L. fischeri in the peridomestic habitat of ACL transmission in SP and recorded it in domestic animal shelters, particularly the pigsties. Studies in the same areas showed it to be present throughout the year: the highest population density was in the hotter and more humid months, but it could be captured in reasonable numbers during colder and dryer weather. Main feeding activity is from dusk onwards, but it was shown also to feed in daylight. More recent studies in this Region of Brazil showed that during the years 1986-1995, this sand fly was present in the domiciliary habitat in $53.6 \%$ of the municipial districts of SP with cases of ACL (Camargo-Neves et al. 2002).

In MG, L. fischeri was shown to be among the four species of sand flies with the highest population density in coffee plantations that were in areas of ACL transmission (Alexander et al. 2002), while its presence was also recorded in areas of ACL in SC (Marcondes et al. 2005).

L. fischeri is considerably anthropophilic, although also feeding on dogs and birds. Recently, in the locality of Posse, district of Petrópolis, RJ, it was shown to have the same feeding pattern in the peridomestic habitat and was the third most frequent species of sand fly captured (Souza et al. 2002). It was also recorded in the Atlantic Forest, during a comparative study with the sand fly species encountered in the caatinga of BA (Dias-Lima et al. 2003).

In considering the low frequency of the sand fly in the forest, Forattini (1973) felt that L. fischeri would have no participation in the transmission of ACL, although it was known to be present in endemic areas in SP (Barretto 1943). Although it has never been found harbouring Leishmania, Coutinho and Barretto (1941) admitted that it could possibly be acting as a secondary vector, based on its high attraction to man and abundance in deforested areas where there were cases of ACL, a conclusion shared by Lainson (1983), who suggested that it might help maintain $L$. $(V$.) braziliensis among wild animals in the surviving pockets of forest.

Lutzomyia (Pintomyia) pessoai (Coutinho \& Barretto, 1940) - Interestingly, this sand fly was, up to 1940, confused with L. fischeri and, according to Barretto (1943), some of the observations regarding the biology of L. fischeri made in the 1930's possibly referred to $L$. pessoai.

In SP, Barretto (1943) indicated the silvatic origin of L. pessoai and showed that the greatest population density of this sand fly was close to areas of recent deforestation, or in forest which was frequently invaded by man and where he had constructed houses and introduced domestic animals. Forattini (1954) recorded it in houses, in SP, which were as far as $300 \mathrm{~m}$ from forest where, he suggested, this sand fly probably bred in the forest soil.

L. pessoai was shown to be present throughout the year and its capture during the coldest months suggests that like L. whitmani it does not hibernate (Barretto 1943). Complementary studies on seasonality indicated its population to be most dense in the hotter and rainier months (Forattini 1973). Its peak feeding activity occurs at dusk and during the first hours of nightfall (Barretto 1943, Forattini 1954, 1960). It may, however, be collected biting man or animals in the forest during the daylight hours (Barretto 1943).

There is circumstantial evidence that $L$. pessoai may participate in the transmission of ACL in the Southeast of Brazil, such as its high population density, considerable attraction to man and its presence inside houses in endemic areas in SP. In this latter region it has been found with flagellates considered to probably be those of a Leishmania species (Pessôa \& Coutinho 1940, 1941). In RS, amplification of DNA has indicated the presence of a parasite of the subgenus Viannia in two specimens of L. pessoai (Silva \& Grunewald 1999). To date however, undoubted $L$. (V.) braziliensis infection of this sand fly has not been demonstrated.

L. (Psychodopygus) wellcomei (Fraiha, Shaw \& Lainson, 1971) - In 1968, the Meridional Mining Company, undertaking mineral exploration in PA, requested the Instituto Evandro Chagas to investigate an alarming number of men acquiring ACL due to $L$. (V.) braziliensis whilst working on road construction through primary forest in the Serra dos Carajás. It required only a few days for one particular sand fly to become highly suspected as the vector, due to its avid feeding on man.

It proved to be a previously undescribed sand fly, which was named $L$. (Psychodopygus) wellcomei Fraiha, Shaw e Lainson, 1971, in honour of Sir Henry Wellcome, founder of the Wellcome Trust, London, who was to sponser the Institute's leishmaniasis programme for nearly 40 further years.

Ward et al. (1973) made a study of sand flies captured during a two month period (December and January) using human bait, rodent-baited Disney traps and aspiration from tree-trunks, all at ground level and captures 
with CDC light traps on platforms built in the trees at five and $11 \mathrm{~m}$ above the forest floor. A total of 23 different species were caught and approximately $65 \%$ of all the sand flies captured while biting man were $L$. wellcomei. Heavy promastigote infections were encountered in three specimens of this sand fly and the parasite was isolated in culture and the skin of hamsters; subsequent studies showed it to be $L$. (V.) braziliensis. Finally, Ryan et al. (1987) obtained experimental transmission of the parasite to hamsters by placing the animals in cages with large numbers of newly caught sand flies. All fed flies were separately maintained in glass vials until they had oviposited, when they were dissected to detect promastigotes and the eggs of all infected specimens maintained in order to rear males for positive identification. This was necessary as the females of $L$. wellcomei are morphologically indistinguishable from those of a sympatric species, L. complexus, while the males have distinctly different morphology.

L. wellcomei is an essentially silvatic and highly anthropophilic species (Ward et al. 1973, Wilkes et al. 1984). In addition, Ward et al. (1973b) found that $25.5 \%$ of all sand flies attracted to rodent-baited traps were of this species: this and the fact that this sand fly has a vertical flight-range of only 1-2 m above ground level, led to their suggestion that the silvatic reservoirs of $L$. wellcomei are terrestrial animals, the most highly suspected being rodents and marsupials (Lainson et al. 1973). The isolation of parasites with the biological characters of $L$. (V.) braziliensis from the rodents Oryzomys concolor, O. capito, Oryzomys nigripes, Akodon arviculoides, Proechimys spp, Rattus rattus and Rhipidomys leucodactylus and the opossum Didelphis marsupialis in Brazil, tended to support this view (Lainson \& Shaw 1970, 1979, Forattini et al. 1972, Forattini 1973, Lainson et al. 1981b, Rocha et al. 1988). Finally, a more definitive identification of this parasite from the Brazilian rodents Bolomys lasiurus and $R$. rattus was obtained by multilocus enzyme electrophoresis (Brandão-Filho et al. 2003).

Regarding its behaviour and seasonality, L. wellcomei is most abundant in the rainy season (November-April) and enters into diapause during the dryer months, when it is very rarely encountered. Limiting forest work to the dryer months can, therefore, greatly reduce the risk of acquiring ACL in areas where this sand fly is found. The great importance of $L$. wellcomei as a vector of $L$. $(V$.) braziliensis is due to its tendency to not only feed at night but also during broad daylight, particularly in cloudy weather. The number of infected females captured during the day was, in fact, found to be greater than that obtained during the night, suggesting that transmission is actually most frequent during the day (Wilkes et al. 1984).

The presence of $L$. wellcomei has been recorded in areas out of the Amazon region, such as in forest of the Serra de Baturité, CE (Ready et al. 1983, Azevedo \& Rangel 1991). The former authors suggested that sand flies recorded as being Lutzomyia squamiventris by $\mathrm{Lu}-$ cena (1953) in the area of Guaramiranga, CE, were possibly L. wellcomei, as the females of the two species, are morphologically very similar.
In the Serra de Baturité area, CE (Queiroz et al. 1994) detected flagellates in L. wellcomei (infection-rate $0.05 \%$ ). Unfortunately, the parasites were not identified and the importance of $L$. wellcomei as a vector of ACL in Northeast Brazil has still to be assessed.

Finally, although L. wellcomei has been found in the Atlantic Rainforest region of state of Pernambuco there has, as yet, been no proven association of this species with local ACL in that region (Andrade et al. 2005, Silva \& Vasconcelos 2005).

Lutzomyia (Psychodopygus) complexa (Mangabeira, 1941) - This sand fly was described from a single male, captured in the municipality of Abaeté, PA, in 1938, by members of the Commission of Studies of American Visceral Leishmaniasis. Like L. wellcomei, the females are highly anthropophilic, although they seem not to share that sand fly's daytime biting habits.

The females of L. complexa and L. wellcomei are morphologically indistinguishable, although the males are easily identified by the structure of the external genitalia. Ready et al. (1991), however, used DNA probes to distinguish the two species and showed that a fragment of DNA highly repetitive for $L$. wellcomei was not detected in either sex of L. complexa.

In Serra dos Carajás, PA, the two species share the same forest habitat, which at first created difficulties in pin-pointing the principal vector of $L$. (V.) braziliensis in that area and necessitated the rearing of males from the eggs of infected females to obtain the all-important males. In a transect running from high up on the range of hills down to the lowland forest, Ready et al. (1984) showed that the predominant species at the higher altitude (700 m, or more, above sea level) was L. wellcomei and that this predominance was slowly reversed with decreasing altitude until $L$. complexus predominated, in large numbers, in the forest at the foot of the hills (200 $\mathrm{m})$ and $L$. wellcomei was completely absent at $150 \mathrm{~m}$ and lower. As ACL due to L. (V.) braziliensis is commonly found in the latter lowland forest, in various regions of PA, this is a clear indication that vectors other than $L$. wellcomei are involved (Shaw et al. 1987). In later studies in Paragominus, where L. wellcomei is uncommon, several females of the squamiventris series were found infected and, as all of the males captured proved to be L. complexa, it was considered sufficient evidence to incriminate this sand fly as the vector of $L$. (V.) braziliensis in that region (Souza et al. 1996).

Azevedo et al. (2002) showed that $L$. complexa represented $8.2 \%$ of all captured sand flies in an area of ACL transmission in Peixoto de Azevedo, MT, although the participation of this species as a vector in this region has yet to be established.

Lutzomyia (Psychodopygus) ayrozai (Barretto \& Coutinho, 1940) - L. ayrozai is recognized as a highly anthropophilic sand fly species in the more mountainous area of Southeast Brazil (Aguiar \& Soucasaux 1984), where it is more frequently found in the hot and humid months: the population suffers reduction during the colder and dryer part of the year. Studies in the Serra dos Órgãos, RJ, showed its feeding activity to start at dusk, extending from approximately 5-12 pm: it feeds, pref- 
erentially, at ground level (Aguiar \& Soucasaux 1984). In the Atlantic Forest, PR, it has been indicated as one of the predominant species; with its population density controlled by such factors as mean monthly temperature and rainfall index (Marcondes et al. 2001).

Leishmania (Viannia) naiffi, a relatively uncommon cause of human ACL in the Amazon Region of Brazil, has been isolated and characterized from L. ayrozai (Arias et al. 1985, Lainson et al. 1990). This sand fly is not so highly anthropophilic in this region, however, as it is in the Serra dos Órgãos, RJ.

Lutzomyia (Psychodopygus) paraensis (Costa Lima, 1941) - This sand fly was first described from a male specimen captured near Belém, PA. Observations on its biology were made in Monte Claro, north PA (Lainson et al. 1979), who suggested that the insect's nocturnal feeding habits would give it little opportunity to feed on man, whose activities in the forest are usually during the daylight hours.

Following studies in primary forest of the Serra dos Carajás, PA, an area of high transmission of $L$. (V.) braziliensis, Lainson et al. (1973) discussed the importance of sand flies of the subgenus Psychodopygus (given generic ranking by the authors). In addition to infections in L. wellcomei, heavy promastigote infections were also found in two out of $175 \mathrm{~L}$. paraensis $(1.14 \%)$ and one out of 127 L. amazonensis $(0.79 \%)$. No proven infection resulted following intradermal inoculation of hamsters with the parasites from the latter two species of sand flies, although a small but persistent swelling was noted at the site of inoculation, some two or three months later. Amastigotes were not demonstrable in the lesions, although intradermal subinoculation of the triturated skin into further hamsters produced a similar small and reddened swelling. The lesions in hamster skin due to $L$. (V.) braziliensis isolated from man and L. wellcomei in this area are known to be slow in development, inconspicuous and to contain very scanty amastigotes: in addition, $L$. (V.) naiffi may behave in a similar fashion, or even produce a completely occult infection which can be detected only by subsequent culture of skin from the area of inoculation. Further isolation and identification of these parasites from L. paraensis and L. amazonensis are clearly needed in the Serra dos Carajás, PA, but as isolates of $L$. (V.) naiffi have been made from both $L$. ayrozai and L. paraensis, elsewhere in Amazon Region of Brazil (Arias et al. 1985, Lainson et al. 1990), it remains likely that they were this parasite.

Lutzomyia (Psychodopygus) amazonensis (Root, 1934) - We have mentioned the finding of heavy promastigote infection in this anthropophilic sand fly, in the discussion on L. paraensis. It was captured in primary forest in the Serra dos Carajás, PA, an area of high incidence of ACL due to $L$. (V.) braziliensis and further attempts are needed to isolate and characterize its parasite.

L. amazonensis is widely distributed in primary forest throughout the Amazon Region. In Brazil it has been reported in PA, AM, AC, RO, AP and RR.
In neighbouring countries it has been recorded in Bolivia, Colombia, Ecuador, French Guiana, Peru, Suriname and Venezuela.

Lutzomyia (Psychodopygus) hirsuta hirsuta (Mangabeira, 1942) - This species is commonly encountered in captures of man-biting sand flies and the females can easily be confused with those of some other anthropophilic species. It has been shown to host a Leishmania species of the subgenus Viannia (Ryan et al. 1987, R Lainson \& EF Rangel, unpublished observations).

The former authors encountered three infected specimens in Tucuruí, PA and a single infected female was found by the latter authors in forest near Além Paraíba, MG, the type locality of $L$. (V.) braziliensis.

Lutzomyia hirsuta hirsuta is widely distributed in the Amazon Basin and, in addition to Brazil, has been recorded in Colombia, Ecuador, Peru, Bolivia, French Guiana and Suriname.

Lutzomyia (Trichophoromyia) ubiquitalis (Mangabeira, 1942) - This species was first described by Mangabeira, following a study of males only, taken from the burrows of the armadillo Dasypus novemcinctus (Xenarthra) and the paca Agouti paca (Rodentia) and from specimens attracted to a horse, in the locality of Aurá, near Belém, PA. It is the first species of the subgenus Trichophoromyia to be incriminated as a vector of a species of Leishmania (Lainson \& Shaw 1998).

In 1983, in the Serra dos Carajás, PA, a Leishmania was isolated from a single female specimen of this sand fly and identified only as a member of the subgenus Viannia by its pyloric development in the sand fly. Later comparison of the morphology and isoenzyme profiles of this parasite and another unidentified Leishmania species from a case of ACL acquired on the outskirts of Belém, PA in 1981, showed the two isolates to clearly be the same parasite: it differed from all other species of Leishmania known in the Amazon Region and was named Leishmania (Viannia) lainsoni (Silveira et al. 1987). Later, the reservoir host of the parasite was shown to be the large rodent Agouti paca (Silveira et al. 1991a) in the burrows of which Mangabeira had first found L. ubiquitalis.

During further eco-epidemiological studies in the same area near Belém, the parasite was re-encountered in eight more specimens of L. ubiquitalis and further isolates were made from cases of ACL (Silveira et al. 1991b).

Surprisingly, L. ubiquitalis was found disinclined to bite man in the field. It was noted, however, that when retained in the laboratory for some time it fed on him readily and when entomological studies were resumed in the area where the infected sand flies were caught, a single female was finally observed to feed and engorge on a man's arm. It was suggested that, in nature, certain factors or changing conditions stimulate $L$. ubiquitalis to attack man and could be induced in the laboratory (Lainson et al. 1992).

Tojal da Silva et al. (2006) characterized isolates of Leishmania isolated from man in an area of intense 
ACL transmission in Rio Branco, AC, as $L$. (V.) guyanensis, $L$. (V.) braziliensis and $L$. (V.) lainsoni and research on potential vectors by Azevedo et al. (2008) led to the suggestion that in that area, too, the vector of the latter parasite is L. ubiquitalis.

Lutzomyia (Lutzomyia) gomezi (Nitzulescu, 1931) - Most first descriptions of sand fly species have been based on male specimens, but that of $L$. gomezi was made with the female; it was captured in the area of San Cristobal, state of Tachira, Venezuela.

Up till now, information on the role of $L$. gomezi as a vector of ACL is scanty and comes mainly from Panamá, where the major vector of $L$. (V.) panamensis is considered to be Lutzomyia trapidoi, but with L. gomezi acting as a secondary vector due to its considerable attraction to man (Johnson et al. 1963, Christensen et al. 1969).

In Brazil, this sand fly has been recorded in the states of Maranhão, Goiás, AC, AP, AM, RO, RR, PA, MT and $\mathrm{BA}$ and in other countries, in Peru, French Guiana, Venezuela, Colombia, Ecuador, Costa Rica, Honduras, El Salvador, Panama, Nicaragua and Trinidad (Young \& Duncan 1994, Aguiar \& Medeiros 2003).

Workers in the Instituto Evandro Chagas, Belém, PA have, on several occasions, encountered specimens of $L$. gomezi heavily infected with promastigotes, the development of which was the same as that of Leishmania species in the subgenus Viannia. They were, however, unable to isolate the parasite for characterization. Its failure to produce a detectable infection after intradermal inoculation into the skin of hamsters is notably similar to the frequent production of occult infection by $L$. $(V$.) naiffi in the same animal. L. gomezi feeds on a variety of wild animals and possibly they include the armadillo $D$. novemcinctus, the only known host of this parasite.

Lutzomyia (Viannamyia) tuberculata (Mangabeira, 1941) - In 1979 a Leishmania species of the subgenus Viannia was isolated by workers of the Instituto Evandro Chagas from a single specimen of this sand fly taken from a large tree-trunk in the Utinga forest, near Belém, PA. The parasite, maintained in liquid nitrogen, remained uncharacterized until Braga et al. (2003) showed it to differ from all other known Leishmania species recorded in Amazon Region of Brazil and named it Leishmania (Viannia) utingensis.

Till now, the wild mammalian host of the parasite is unknown and it has not been found infecting man. As $L$. tuberculata shows no inclination to bite man it is perhaps unlikely that human ACL due to $L$. (V.) utingensis exists. If, however, there is some other sand fly host which is sometimes attracted to man, cases may well be found in the future.

Lutzomyia tuberculata is commonly found on the trunks of large trees in primary or secondary forest and the mammalian host of $L$. ( V.) utingensis is, therefore, likely to be an arboreal animal. In Brazil, L. tuberculata is widely distributed throughout the Amazon Basin and in neighbouring countries such as French Guiana, Suriname, Colombia and Venezuela. In Central America it has been recorded in Panama.
The general opinion is that the genus Leishmania evolved from a monogenetic insect flagellate and, this being so, the phlebotomine sand fly is best regarded as the primary host of this parasite (Lainson 1997). During the sand fly's blood meal, inoculated flagellates must have eventually adapted to spend part of the parasite's life-cycle in the secondary, vertebrate host, in the amastigote form, thus forming a reservoir of infection for further sand flies.

We have little knowledge regarding the degree of specificity of the Leishmania species for their sand fly hosts in nature. In many instances the results of experiments, using different colonized sand fly species in the laboratory, may be misleading due to the excessive number of amastigotes (or promastigotes from in vitro cultures) fed to these insects: this may overpower a sand fly's resistance to infection by a given Leishmania species. Ecological studies, however, strongly suggest natural barriers which limit the life-cycle of leishmanial parasites to certain sand fly species, or others that are closely related.

The steadily increasing number of neotropical Leishmania species being described is largely due to isolation of the parasites from cases of human leishmaniasis. There are, however, several species which are not yet known to infect man, most probably because their sand fly vectors are not attracted to him: notable examples are Leishmania (Leishmania) hertigi and Leishmania (Leishmania) deanei of porcupines, Leishmania (Leishmania) enriettii of guinea-pigs and $L$. (V.) utingensis of the sand fly $L$. tuberculata. Just how many more species of Leishmania there are to be discovered in other non-anthropophilic sand flies remains to be seen and some idea will only be gained by the continued dissection of large numbers of these and the isolation and characterization of any parasites detected. A daunting task, considering that almost 400 species of sand flies of the genus Lutzomyia have been recorded in the Americas (Young \& Duncan 1994) and that the list will doubtless continue to grow!

\section{ACKNOWLEDGEMENTS}

To Simone Miranda da Costa, from Laboratório de Transmissores de Leishmanioses, Instituto Oswaldo Cruz, and Vânia Barbosa da Silva Araújo, from Instituto Evandro Chagas, for their assistance in the bibliography.

\section{REFERENCES}

Afonso MMS, Gomes AC, Meneses CRV, Rangel EF 2005. Studies on the feeding habits of Lutzomyia (N.) intermedia (Diptera: Psychodidae), vector of cutaneous leishmaniasis in Brazil. Cad Saude Publica 21: 1816-1820.

Aguiar GM, Medeiros WM 2003. Dstribuição regional e habitats das espécies de flebotomíneos do Brasil. In Flebotomíneos do Brasil. EF Rangel, R Lainson (eds.), Fiocruz, Rio de Janeiro, p. 207-255.

Aguiar GM, Soucasaux T 1984. Ecological aspects of Phlebotomus of Parque Nacional da Serra dos Órgãos, Rio de Janeiro. I. Monthly frequency in human baits (Diptera: Psychodidae: Phlebotominae). Mem Inst Oswaldo Cruz 79: 197-209.

Alexander B, Oliveira EB, Haigh E, Almeida LL 2002. Transmission of Leishmania in coffee plantations of Minas Gerais, Brazil. Mem Inst Oswaldo Cruz 97: 627-630. 
Andrade-Filho JD, Galati EA, Falcão AL 2004. Biology of the first generation of a laboratory colony of Nyssomyia intermedia (Lutz $\&$ Neiva, 1912) and Nyssomyia neivai (Pinto, 1926) (Diptera: Psychididae). Mem Inst Oswaldo Cruz 99: 597-601.

Andrade MS, Valença HF, da Silva AL, Almeida EL, de Brito ME, Brandão-Filho SP 2005. Sand fly fauna in a military training area endemic for American tegumentary leishmaniasis in the Atlantic Rain Forest region of Pernambuco, Brazil. Cad Saude Publica 21: 1761-1767.

Aragão HB 1922. Leishmaniose tegumentar e a sua transmissão pelo Phlebotomus. Mem Inst Oswaldo Cruz 82: 143.

Araújo Filho NA 1979. Epidemiologia da leishmaniose tegumentar na Ilha Grande, PhD Thesis, Universidade Federal do Rio de Janeiro, Rio de Janeiro, 144 pp.

Arias JR, Freitas RA 1977a. On the vectors of cutaneous leishmaniasis in the Central Amazon of Brazil. I. Preliminary findings. Acta Amazonica 7: 293-294.

Arias JR, Freitas RA 1977b. Flebótomos da Amazônia Central. 1. Resultados obtidos das capturas feitas com iscas humanas e eqüina (Diptera: Psychodidae). Acta Amazonica 7: 507-527.

Arias JR, Freitas RA 1978. Sobre os vetores de leishmaniose cutânea na Amazônia Central do Brasil. 2. Incidência de flagelados em flebótomos selváticos. Acta Amazonica 8: 387-396.

Arias JR, Miles MA, Naiff RD, Povoa MM, de Freitas RA, Biancardi CB, Castellon EG 1985. Flagellate infections of Brazilian sand flies (Diptera: Psychodidae): isolation in vitro and biochemical identification of Endotrypanum and Leishmania. Am J Trop Med Hyg 34: 1098-1108.

Azevedo ACR 2008. Contribuição ao conhecimento da fauna de flebotomineos do Estado do Acre com ênfase em Lutzomyia (Nyssomyia) umbratilis Ward \& Fraiha, 1977, importante transmissor de leishmaniose tegumentar americana na Amazônia: biologia, morfologia, morfometria e discussão da identidade taxonômica, PnD Thesis, Instituto Oswaldo Cruz, Rio de Janeiro, 144 pp.

Azevedo ACR, Bessa-Luz S, Vilela ML, Rangel EF 1993. Studies on the sand fly fauna of Samuel Ecological Station, Porto Velho municipality, Rondônia state, Brazil. Mem Inst Oswaldo Cruz 88: 509-512.

Azevedo ACR, Costa SM, Pinto MC, Souza JL, Cruz HC, Vidal J, Rangel EF 2008. Studies on the sand fly fauna (Diptera: Psychodidae: Phlebotominae) from transmission areas of American cutaneous leishmaniasis in state of Acre, Brazil. Mem Inst Oswaldo Cruz 103: 760-767.

Azevedo ACR, Lainson R, Afonso MMS, Rangel EF 2005. Estudio sobre Lutzomyia (Nyssomyia) umbratilis Ward \& Frailha, 1977 (Psychodidae: Phlebotominae), vector de la leishmaniasis tegumentar Americana, en el Amazonas. Salud Ciencia 14: 30-33.

Azevedo ACR, Rangel EF 1991. A study of sand fly species (Diptera: Psychodidae: Phlebotominae) in a focus of cutaneous leishmaniasis in the municipality of Baturité, Ceará, Brazil. Mem Inst Oswaldo Cruz 86: 405-410.

Azevedo ACR, Rangel EF, Costa EM, David J, Vasconcelos AW, Lopes VG 1990. Natural infection of Lutzomyia (Nyssomyia) whitmani (Antunes \& Coutinho, 1939) by Leishmania of the braziliensis complex in Baturite, Ceará state, Northeast Brazil. Mem Inst Oswaldo Cruz 85: 251.

Azevedo AC, Souza NA, Meneses CR, Costa WA, Costa SM, Rangel EF 2002. Ecology of sand flies (Dipetra: Psychodidae: Phlebotominae) in the north of the state of Mato Grosso, Brazil. Mem Inst Oswaldo Cruz 97: 459-464.
Barbosa MG, Fé NF, Marcião AH, Silva AP, Monteiro WM, Guerra JA 2008. Sand fly fauna (Diptera: Psychodidae) in a focus of American cutaneous leishmaniasis on the urban periphery of Manaus, state of Amazonas. Rev Soc Bras Med Trop 41: 485-491.

Barreto AC, Vexenat JA, Cuba-Cuba CA, Marsden PD 1982. Fauna flebotomínica de uma região endêmica de leishmaniose cutâneomucosa no Estado da Bahia. IX Reunião Anual sobre Pesquisa Básica em Doenças de Chagas, 147 pp.

Barretto MP 1943. Observações sobre a biologia em condições naturais dos flebótomos do estado de São Paulo (Ditera: Psychodidae), Tese de Livre-Docência, Faculdade de Medicina da USP, São Paulo, 162 pp.

Braga RR, Lainson R, Ishikawa EAY, Shaw JJ 2003. Leishmania (Viannia) utingensis n.sp., a parasite from the sand fly Lutzomyia (Viannamyia) tuberculata in Amazonian Brazil. Parasite 10: 111-118.

Brandão-Filho SP, Brito ME, Carvalho FG, Ishikawa EA, Cupolillo E, Floeter-Winter 1, Shaw JJ 2003. Wild and synanothropic hosts of Leishmania (Viannia) braziliensis in the endemic cutaneous leishmaniasis locality of Amaraji, Pernambuco state, Brazil. Trans R Soc Trop Med Hyg 97: 291-296.

Camargo-Neves VL, Gomes AC, Antunes JL 2002. Correlation of the presence of phlebotominae species (Diptera: Psychodidae) with records of American tegumentary leishmaniasis cases in the state of São Paulo, Brazil. Rev Soc Bras Med Trop 35: 299-306.

Campbell-Lendrum DH, Brandão-Filho SP, Ready PD, Davies CR 1999. Host and/or site loyalty of Lutzomyia whitmani (Diptera: Psychodidae) in Brazil. Med Vet Entomol 13: 209-211.

Carvalho GM, Andrade Filho JD, Falcão AL, Rocha Lima AC, Contijo CM 2008. Naturally infected Lutzomyia sand flies in a Leishmania-endemic area of Brazil. Vector Borne Zoonotic Dis 8: 407-414.

Casanova C, Natal D, Santos FA 2009. Survival, population size and gonotrophic cycle duration of Nyssomyia neivai (Diptera: Psychodidae) at an endemic area of American cutaneous leishmaniasis in Southeastern Brazil. J Med Entomol 46: 42-50.

Christensen HA, Arias JR, de Vasques AM, de Freitas R 1982. Hosts of sand fly vectors of Leishmania braziliensis guyanensis in the central Amazon of Brazil. Am J Trop Med Hyg 31: 239-242.

Christensen HA, Herrer A, Telford SR 1969. Leishmania braziliensis from Lutzomyia panamensis in Panama. J Parasitol 55: 1090-1091.

Costa SM, Cechinel M, Bandeira V, Zannuncio JC, Lainson R, Rangel EF 2007. Lutzomyia (Nyssomyia) whitmani s.l. (Antunes \& Coutinho, 1939) (Diptera: Psychodidae: Phlebotominae) and the epidemiology of American cutaneous leishmaniasis in Brazil. Mem Inst Oswaldo Cruz 102: 149-153.

Coutinho JO, Barretto MP 1941. Dados bionômicos sobre o Phlebotomus fischeri Pinto, 1926 (Diptera: Psychodidae). Rev Bras Biol 1: 423-429.

de Castro EA, Luz E, Telles FQ, Pandey A, Biseto A, Dinaiski A, Sbalqueiro I, Soccol VT 2005. Eco-epidemiological survey of Leishmania (Viannia) braziliensis American cutaneous and mucocutaneous leishmaniasis in Ribeira Valley River, Paraná state, Brazil. Acta Trop 93: 141-149.

Dias-Lima AG, Guedes ML, Sherlock IA 2003. Horizontal stratification of the sand fly fauna (Diptera: Psychodidae) in a transitional vegetation between caatinga and tropical rain forest, state of Bahia, Brazil. Mem Inst Oswaldo Cruz 98: 733-737. 
Dias-Sversutti A, Scodro RB, Reinhold-Castro KR, Neitzke HC, Teodoro U 2007. Preliminary study on feeding preference of Nyssomyia neivai (Pinto) and Nyssomyia whitmani (Antunes \& Coutinho) (Diptera: Psychodidae) in a rural area of the state of Paraná, South Brazil. Neotrop Entomol 36: 953-959.

Dorval ME, Cristaldo G, Rocha HC, Alves TP, Alves MA, Oshiro ET, Brazil RP, Galati EA, Cunha RV 2009. Phlebotomine fauna (Diptera: Psychodidade) of an endemic area in the state of Mato Grosso do Sul, Brazil. Mem Inst Oswaldo Cruz 104: 695-702.

Esterre P, Chippaux JP, Lefait JF, Dedet JP 1986. Evaluation of a cutaneous leishmaniasis control program in a forest village of French Guyana. Bull World Health Organ 64: 559-565.

Falqueto A 1995. Especificidade alimentar de flebotomíneos em duas áreas endêmicas de leishmaniose tegumentar no estado do Espírito Santo, PhD Thesis, Fiocruz, Rio de Janeiro, 84 pp.

Feliciangeli MD, Ramirez Perez J, Ramirez A 1985. First Venezuelan record of Lutzomyia umbratilis Ward \& Fraiha, 1977 (Diptera: Psychodidae), a proven vector of Leishmania braziliensis guyanensis. Trans R Soc Trop Med Hyg 79: 878.

Ferreira AL, Sessa PA, Varejão JB, Falqueto A 2001. Distribution of sand flies (Diptera: Psychodidae) at different altitudes in an endemic region of American cutaneous leishmaniasis in the state of Espirito Santo, Brazil. Mem Inst Oswaldo Cruz 96: 1061-1067.

Floch H, Abonnenc E 1944. Phlébotomes de Guyane Française (X). Sur lês femelles a segment des palpes court. Description du male de P. Anduzei, Institut Paster Guyane, French Guiana, 24 pp.

Forattini OP 1953. Nota sobre criadouros naturais de flebótomos em dependências peri-domiciliares no estado de São Paulo. Arq Fac Hig Saude Publica Univ Sao Paulo 7: 157-168.

Forattini OP 1954. Nota sobre a biologia de Phlebotomus (Diptera: Psychodidae) em região da Bacia do Rio Paraná (Brasil). Arq Fac Hig Saude Publica Univ Sao Paulo 8: 15-136.

Forattini OP 1960. Novas observações sobre a biologia de flebótomos em condições naturais (Diptera: Psychodidae). Arq Hyg Sao Paulo 25: 209-215.

Forattini OP 1973. Entomologia Médica, vol. 4, Editora Edgard Blücher \& Editora da Universidade de São Paulo, São Paulo, 658 pp.

Forattini OP, Pattoli DBG, Rabello EX, Ferreira OA 1972. Infecção natural de flebotomíneos em foco enzoótico de leishmaniose tegumentar no estado de São Paulo, Brasil. Rev Saude Publica 6: $431-433$

Forattini OP, Rabello EX, Serra OP, Cotrim MD, Galati EAB, Barata JMS 1976. Observações sobre a transmissão da leishmaniose tegumentar no estado de São Paulo, Brasil. Rev Saude Publica 10: $31-43$.

Forattini OP, Santos MR 1952. Nota sobre infecção natural de Phlebotomus intermedius Lutz \& Neiva, 1912, por formas em leptomonas, em um foco de leishmaniose tegumentar americana. Arq Hig S Paulo 17: 171-174.

Fraiha H, Shaw J, Lainson R 1971. Phlebotominae brasileiros. II. Psychodopygus wellcomei, nova espécie antropófila de flebótomos do grupo squamiventris do sul do estado do Pará, Brazil. Mem Inst Oswaldo Cruz 69: 489-500.

Fraiha H, Ward RD 1974. A new species of Psychodopygus Mangabeira (Diptera: Phlebotominae) from the Transamazonica highway, Pará state, Brazil. Bull Ent Res 64: 209-212.

França F, Lago EL, Tada S, Costa JM, Vale K, Oliveira J, Costa MA, Osaki M, Cheever L, Netto EM, Barretto AC, Johnson WD, Marsden PD 1991. An outbreak of human Leishmania (Viannia) braziliensis infection. Mem Inst Oswaldo Cruz 86: 169-174.
Galati EAB 2003. Morfologia e taxonomia. In Flebotomíneos do Brasil, EF Rangel, R Lainson (eds.), Fiocruz, Rio de Janeiro, p. 23-176.

Galati EAB, Nunes VLB, Dorval MEC, Oshiro ET, Cristaldo G, Espínola MA, Rocha HC, Garcia WB 1996. Study of the phlebotomines (Diptera: Psychodidade) in area of cutaneous leishmaniasis in the Mato Grosso state, Brazil. Rev Saude Publica 30: 115-128.

Gil LH, Basano AS, Souza AA, Silva MG, Barata I, Ishikawa EA, Camargo LM, Shaw JJ 2003. Recent observations on the sand fly (Diptera: Psychodidae) fauna of the state of Rondônia, western Amazonia, Brazil: the importance of Psychodopygus davisi as a vector of zoonotic cutaneous leishmaniasis. Mem Inst Oswaldo Cruz 98: 751-755.

Gomes AC 1994. Sand fly vectorial ecology in the state of São Paulo. Mem Inst Oswaldo Cruz 89: 457-460.

Gomes AC, Galati EA 1989. Aspectos ecológicos da leishmaniose tegumentar americana. 7. Capacidade vetorial flebotominea em ambiente florestal primário do sistema da Serra do Mar, região do Vale do Ribeira, estado de São Paulo, Brasil. Rev Saude Publica 23: 136-142.

Gomes AC, Rabello EX, Santos JFL, Galati EAB 1986. Ecological aspects of American cutaneous leishmaniasis. 4. Observation on the endophilic behavior of the sand fly and the vectorial role of Psychodopygus intermedius in the Ribeira Valley region of the $\mathrm{S}$. Paulo state, Brazil. Rev Saude Publica 20: 280-287.

Guerra JA, Barbosa MG, Loureiro AC, Coelho CP, Rosa GG, Coelho LI 2007. American tegumentary leishmaniasis in children: epidemiological aspects of cases treated in Manaus, Amazonas, Brazil. Cad Saude Publica 23: 2215-2223.

Guimarães FN 1955. Estudo de um foco de leishmaniose mucocutânea na baixada fluminense (estado do Rio de Janeiro). Mem Inst Oswaldo Cruz 53: 1-11.

Guimarães FN, Bustamante FMA 1954. Aplicação domiciliar de DDT como base de profilaxia das leishmanioses. Estudos de um foco de leishmaniose muco-cutânea cinco anos depois da aspersão periódica com aquele inseticida. Rev Bras Malariol 6: 127-130.

Guimarães FN, Costa O 1966. Novas observações sobre a Leishmania isolada de "Oryzomys goeldi" na Amazônia (4 nota). Hospital RJ 69: 161-168.

Hoch A, Ryan L, Vexenet JA, Rosa AC, Barretto AC 1986. Isolation of Leishmania braziliensis braziliensis and other trypanosomatids from phlebotomines in mucocutaneous leishmaniasis endemic area, Bahia, Brazil. Mem Inst Oswaldo Cruz 81 (Suppl.): BI 44.

Ishikawa EAY, Ready PD, de Souza AA, Day JC, Rangel EF, Davies CR, Shaw JJ 1999. A mitochondrial DNA phylogeny indicates close relationship between populations of Lutzomyia whitmani (Diptera: Psychodidae: Phlebotominae) from the rain-forest region of Amazônia and Northeast Brazil. Mem Inst Oswaldo Cruz 94: 339-345.

Johnson PT, McConnell E, Hertig M 1963. Natural infections of leptomonad flagellates in Panamanian Phlebotomus sand flies. Exp Parasitol 14: 107-122.

Lainson R 1983. The American leishmaniases: some observation on their ecology and epidemiology. Trans R Soc Trop Med Hyg 77: 569-596.

Lainson R 1988. Ecological interactions in the transmission of the leishmaniases. Philos Trans R Soc Lond Series B 321: 389-404.

Lainson R 1997. On Leishmania enriettii and other enigmatic Leishmania species of the neotropics. Mem Inst Oswaldo Cruz 92: 377-387.

Lainson R, Braga RR, Souza AA, Povoa MM, Ishihawa EAY, Silveira 
FT 1989. Leishmania (Viannia) shawi sp.n, a parasite of monkeys, sloths and procyonids in Amazonian Brazil. Ann Parasit Hum Comp 64: 200-207.

Lainson R, Shaw JJ 1968. Leishmaniasis in Brazil I. Observations on enzootic rodent leishmaniasis - Incrimination of Lutzomyia flaviscutellata (Mangabeira) as the vector in the lower Amazonian Basin. Trans R Soc Trop Med Hyg 62: 385-395.

Lainson R, Shaw JJ 1970. Leishmaniasis in Brazil. V: Studies on the epidemiology of cutaneous leishmaniasis in Mato Grosso state and observations on two distinct strains of Leishmania isolates from man and forest animals. Trans $R$ Soc Trop Med Hyg 64: 654-667.

Lainson R, Shaw JJ 1972. Leishmaniasis of the New World: taxonomic problems. Brit Med Bull 28: 44-48.

Lainson R, Shaw JJ 1979. The role of animals in the epidemiology of South American leishmaniasis. In WHR Lumsden, DA Evans, Biology of the Kinetoplastida, vol. 2, Academic Press, London, p. 1-116.

Lainson R, Shaw JJ 1987. Evolution, classification and geographic distribution. In W Peters, R Killick-Kendrick (eds.), The leishmaniases in biology and medicine, vol. 1, Academic Press, London, 1-20.

Lainson R, Shaw JJ 1998. New World leishmaniasis. The neotropical Leishmania species. In FEG Cox, JP Kreier, D Wakelin (eds.), Topley \& Wilson's microbiology \& microbiol infections, 9th ed., vol. 5, Parasitology, Arnold, London, p. 242-266.

Lainson R, Shaw JJ, Póvoa M 1981a. The importance of edentates (sloths and anteaters) as primary reservoirs of Leishmania braziliensis guyanensis, causative agent of "pian-bois" in North Brazil. Trans R Soc Trop Med Hyg 75: 611-612.

Lainson R, Shaw JJ, Póvoa M 1981b. Leishmaniasis in Brazil: XVI. Isolation and identification of Leishmania species from sand flies, wild mammals and man in north Pará state, with particular reference to L. braziliensis guyanensis causative agent of "pianbois". Trans R Soc Trop Med Hyg 75: 530-536.

Lainson R, Shaw JJ, Silveira FT, Braga RR, Ishikawa EAY 1990. Cutaneous leishmaniasis of man due to Leishmania (Viannia) naiffi. Ann Parasitol Hum Comp 65: 282-284.

Lainson R, Shaw JJ, Silveira FT, de Souza AA, Braga RR, Ishikawa EA 1994. The dermal leishmaniases of Brazil, with special reference to the eco-epidemiology of the disease in Amazônia. Mem Inst Oswaldo Cruz 89: 435-443.

Lainson R, Shaw JJ, Souza AAA, Silveira FT, Falqueto A 1992. Further observations on Lutzomyia ubiquitalis (Psychodidae: Phlebotominae), the sand fly vector of Leishmania (Viannia) lainsoni. Mem Inst Oswaldo Cruz 87: 437-439.

Lainson R, Shaw JJ, Ward RD, Fraiha H 1973. Leishmaniasis in Brazil. IX. Considerations on the Leishmania braziliensis complex. Importance of sand flies of the genus Psychodopygus (Mangabeira) in the transmission of Leishmania braziliensis braziliensis in North Brazil. Trans R Soc Trop Med Hyg 67: 184-196.

Lainson R, Shaw JJ, Ward RD, Ready PD, Naiff RD 1979. Leishmaniasis in Brazil: XIII. Isolation of Leishmania from armadillos (Dasypus novemcinctus) and observation on the epidemiology of cutaneous leishmaniasis in north Pará state. Trans $R$ Soc Trop Med Hyg 73: 239-242.

Lainson R, Strangways-Dixon J 1964. The epidemiology of dermal leishmaniasis in British Honduras. Parte III. Reservoir-host of Leishmania mexicana among forest rodents. Trans $R$ Soc Trop Med Hyg 58: 136-153.
Lainson R, Ward RD, Shaw JJ 1976. Cutaneous leishmaniasis in North Brazil: Lutzomyia anduzei as a major vector. Trans $R$ Soc Trop Med Hyg 70: 171-172.

Le Pont F, Pajot FX 1980. La leishmaniose en Guyane Française. I. Etude de l'ecologie et du taux d'infection naturelle d'un vecteur Lutzomyia (Nyssomyia) umbratilis Ward et Fraiha, 1977 en saison sèche. Considerations epidémiologiques. Cah. ORSTOM Ser Ent Med Parasitol 18: 359-383.

Lucena DT 1953. Flebótomos do Nordeste. Morfologia de algumas espécies e sua distribuição. Papéis Avulsos de Zoologia 11: 89-107.

Lutz A, Neiva A 1912. Contribuição para o conhecimento das espécies do gênero Phlebotomus existentes no Brasil. Mem Inst Oswaldo Cruz 4: 82-95.

Luz E, Membrive N, Castro EA, Dereure J, Pratlong F, Dedet JA, Pandey A, Thomaz-Soccol V 2000. Lutzomyia whitmani (Diptera: Psychodidae) as vector of Leishmania (V.) braziliensis in Paraná state, Southern Brazil. Ann Trop Med Parasitol 94: 623-631.

Marcondes CB 1996. A redescription of Lutzomyia (Nyssomyia) intermedia (Lutz \& Neiva, 1912) and resurrection of L. neivai (Pinto, 1926) (Diptera: Psychodidae: Phlebotominae). Mem Inst Oswaldo Cruz 91: 457-462.

Marcondes CB, Bittencourt IA, Stoco PH, Eger I, Grisard EC, Steindel M 2009. Natural infection of Nyssomyia neivai (Pinto, 1926) (Diptera: Psychodidae: Phlebotominae) by Leihmania (Viannia) spp in Brazil. Trans R Soc Trop Med Hyg 27, in press.

Marcondes CB, Conceição MB, Portes MG, Simão BP 2005. Phlebotomine sand flies in a focus of dermal leishmaniasis in the eastern region of the Brazilian state of Santa Catarina: preliminary results (Diptera: Psychodidae). Rev Soc Bras Med Trop 38: 353-355.

Marcondes CB, Day JC, Ready PD 1997. Introgression between Lutzomyia intermedia and both $L u$. neivai and Lu. whitmani and their roles as vectors of Leishmania braziliensis. Trans R Soc Trop Med Hyg 91: 725-726.

Marcondes CB, Santos-Neto LG, Lozovei AL 2001. Ecology of phlebotomine sand flies (Diptera: Psychodidae) in Brazilian Atlantic Forest. Rev Soc Bras Med Trop 34: 255-260.

Margonari CS, Dias-Forte CL, Dias ES 2004. Genetic variability in geographical populations of Lutzomyia whitmani elucidated by RAPD-PCR. J Med Entomol 41: 187-192.

Mayrink W, Williams P, Coelho MV, Dias M, Martins AV, Magalhães PA, Costa CA, Falcão AR, Melo MN, Falcão AL 1979. Epidemiology of dermal leishmaniasis in the Rio Doce Valley, state of Minas Gerais, Brazil. Ann Trop Med Parasitol 73: 123-137.

Meneses CR, Cupolillo E, Monteiro F, Rangel EF 2005. Micro-geographical variation among male populations of the sand fly, Lutzomyia (Nyssomyia) intermedia, from an endemic area of American cutaneous leishmaniasis in the state of Rio de Janeiro, Brazil. Med Vet Entomol 19: 38-47.

Oliveira AG, Andrade Filho JD, Falcão AL, Brazil RP 2003. Study of sand flies (Diptera: Psychodidae: Phlebotominae) in the urban area of Campo Grande, Mato Grosso do Sul state, Brazil, from 1999 to 2000. Cad Saude Publica 19: 933-944.

Oliveira MR, Macedo VO, de Carvalho EM, Barral A, Marotti JG, Bittencourt A, de Abreu MV, Orge M de La G, Lessa Hde A, Marsden PD 1995. An evolutionary study of mucosal leishmaniasis (a 7 to 17-year follow-up) due to Leishmania (Viannia) braziliensis in Três Braços, Bahia. Rev Soc Bras Med Trop 28: 325-332.

Passos VNA, Silva RE, Falcão AL 1991. Fauna flebotomínica de municípios da região metropolitana de Belo Horizonte. Rev Soc Bras Med Trop 24 (Suppl. 11): 107. 
Pessôa SB, Coutinho JO 1940. Infecção natural do Phlebotomus pessoai por formas em leptomonas, provavelmente da Leishmania brasiliensis. Rev Biol Hyg 10: 139-142.

Pessôa SB, Coutinho JO 1941. Infecção natural e experimental dos flebótomos pela Leishmania braziliensis no estado de São Paulo. Hospital 20: 25-35.

Peterson AT, Shaw J 2003. Lutzomyia vectors for cutaneous leishmaniasis in Southern Brazil: ecological niche models, predicted geographic distributions and climate change effects. Int J Parasitol 33: 919-931.

Pirmez C, Oliveira-Neto MP, Franco A, Meneses C, Rangel E, Mayrink A, Gonçalves AJ, Fernandes O, Grimaldi G 1997. Edentates as a possible reservoir of $L$. $(V$.) braziliensis in an endemic area of Rio de Janeiro. Mem Inst Oswaldo Cruz 92 (Suppl. I): 119.

Pita-Pereira D, Alves CR, Souza MB, Brazil RP, Bertho AL, Figueiredo AB, Britto CC 2005. Identification of naturally infected Lutzomyia intermedia and Lutzomyia migonei with Leishmania (Viannia) braziliensis in Rio de Janeiro (Brazil) revealed by a PCR multiplex non-isotopic hybridisation assay. Trans $R$ Soc Trop Med Hyg 99: 905-913.

Pita-Pereira D, Souza GD, Zwetsch A, Alves CR, Britto C, Rangel EF 2009. First report of Lutzomyia (Nyssomyia) neivai (Diptera: Psychodidae: Phlebotominae) naturally infected by Leishmania (Viannia) braziliensis in a periurban area of South Brazil using a multiplex polymerase chain reaction assay. Am J Trop Med Hyg 80: 593-595.

Queiroz RG, Vasconcelos IA, Vasconcelos AW, Pessoa FA, Souza RN, David JR 1994. Cutaneous leishmaniasis in Ceará state in Northeasten Brazil: incrimination of Lutzomyia whitmani (Diptera: Psychodidae) as a vector of Leishmania braziliensis in Baturité municipality. Ann J Trop Med Hyg 50: 693-698.

Rangel EF, Azevedo ACR, Andrade CA, Souza NA, Wermelinger ED 1990. Studies on sand fly fauna (Diptera: Psychodidae) in a foci of cutaneous leishmaniasis in Mesquita, Rio de Janeiro state, Brazil. Mem Inst Oswaldo Cruz 85: 39-45.

Rangel EF, Azevedo ACR, Orosko S, Lima JB, Souza NA, Pereira T, Meneses CRV, Costa WA, Cupollilo E, Brahim L 1998. Lutzomyia (Nyssomyia) umbratilis (Ward \& Fraiha, 1977) and the ecology of American cutaneous leishmaniasis in Mato Grosso state. I Bienal de Pesquisa da Fundação Oswaldo Cruz, Fiocruz, Rio de Janeiro, $122 \mathrm{pp}$.

Rangel EF, Barbosa AF, Andrade CA, Souza NA, Wermelinger ED 1992. Development of Leishmania (Viannia) braziliensis Viannia, 1991 in Lutzomyia intermedia (Lutz \& Neiva, 1912) (Diptera: Psychodidae) under experimental conditions. Mem Inst Oswaldo Cruz 87: 235-238.

Rangel EF, Lainson R, Souza AA, Ready P, Azevedo ACR 1996. Variation between geographical populations of Lutzomyia (Nyssomyia) whitmani (Antunes \& Coutinho, 1939) sensu lato (Diptera: Psychodidae: Phlebotominae) in Brazil. Mem Inst Oswaldo Cruz 91: 43-50.

Rangel EF, Lainson R, Souza AA, Ready PD, Azevedo ACR, Papavero N 1994. Lutzomyia (Nyssomyia) whitmani (Antunes \& Coutinho, 1939) (Diptera: Psychodidae: Phlebotominae), a vector of cutaneous leishmaniasis in Brazil. Mem Inst Oswaldo Cruz 89 (Suppl. I): 202.

Rangel EF, Meneses CRV, Cupolillo E, Azevedo ACR, Costa WA, Costa SM 1999. Aspectos da ecologia de Lutzomyia intermedia (Lutz \& Neiva, 1912) e a fauna flebotomínica (Diptera: Psychodidae) em área de transmissão da Leishmania (V.) braziliensis no Rio de Janeiro. Rev Soc Bras Med Trop 32 (Suppl. 1): 115.
Rangel EF, Souza NA, Wermelinger ED, Barbosa AF 1984. Infecção natural de Lutzomyia intermedia (Lutz \& Neiva, 1912) em área endêmica de leishmaniose tegumentar no Estado do Rio de Janeiro. Mem Inst Oswaldo Cruz 79: 395-396.

Rangel EF, Souza NA, Wermelinger ED, Barbosa AF, Andrade CA 1986. Biology of Lutzomyia intermedia Lutz \& Neiva, 1912 and Lutzomyia longipalpis Lutz \& Neiva, 1912 (Diptera: Psychodidae) under experimental conditions. I. Feeding aspects of larvae and adults. Mem Inst Oswaldo Cruz 81: 431-438.

Ready PD, Day JC, Souza AA, Rangel EF, Davies CR 1997. Mitochondrial DNA characterization of populations of Lutzomyia whitmani (Diptera: Psychodiade) incriminated in the peridomestic and silvatic transmission of Leishmania species in Brazil. Bull Ent Res 87: 187-195.

Ready PD, Lainson R, Shaw JJ 1983. Leishmaniasis in Brazil: XX. Prevalence of "enzootic rodent leishmaniasis" (Leishmania mexicana amazonensis) and apparent absence of pian-bois (Le. braziliensis guyanensis), in plantations of introduced tree species and in other non-climax forests in eastern Amazonia. Trans $R$ Soc Trop Med Hyg 77: 775-785.

Ready PD, Lainson R, Shaw JJ 1984. Habitat and seasonality of Psychodopygus wellcomei help incriminate it as a vector of Leishmania in Amazônia and Northeast Brazil. Trans R Soc Trop Hyg 78: 543-544.

Ready PD, Lainson R, Shaw JJ, Souza AA 1991. DNA probes for distinguishing Psychodopygus wellcomei from Psychodopygus complexux (Diptera: Psychodidae). Mem Inst Oswaldo Cruz 86: 41-49.

Ready PD, Lainson R, Shaw JJ, Ward D 1986. The ecology of Lutzomyia umbratilis (Ward \& Fraiha, 1977) (Diptera: Psychodiade), the major vector to man of Leishmania braziliensis guyanensis in north-eastern Amazonian Brazil. Bull Entomol Res 76: 21-40.

Ready PD, Ribeiro AL, Lainson R, de Alencar JE, Shaw JJ 1983. Presence of Psychodopygus wellcomei (Diptera: Psychodidae), a proven vector of Leishmania braziliensis braziliensis, in Ceara state. Mem Inst Oswaldo Cruz 78: 235-236.

Ready PD, Souza AA, Rebêlo JMM, Day JC, Silveira FT, CampbellLendum D, Davies CR, Costa JML 1998. Phylogenetic species and domesticity of Lutzomyia whitmani at the south-east boundary of Amazonian Brazil. Bull Entomol Res 87: 187-195.

Rocha NMM, Melo MN, Babá EH, Dias M, Michalick MSM, Da Costa CA, Williams P, Mayrink W 1988. Leishmania braziliensis braziliensis isolated from Akodon arviculoides captured in Caratinga, Minas Gerais, Brazil. Trans R Soc Trop Med Hyg 82: 68.

Ryan L, Lainson R, Shaw JJ 1987. Leishmaniasis in Brazil. XXIV. Natural flagellate infections of sandflies (Diptera: Psychodidae) in Pará state, with particular reference to the role of Psychodopygus wellcomei as the vector of Leishmania braziliensis braziliensis in t he Serra dos Carajás. Trans $R$ Soc Trop Med Hyg 81: 353-359.

Ryan L, Silveira FT, Lainson R, Shaw JJ 1984. Leishmanial infections in Lutzomyia longipalpis and Lu. antunesi (Diptera: Psychodidae) on the island of Marajó, Pará state, Brazil. Trans R Soc Trop Med Hyg 78: 547-548.

Ryan L, Vexenet A, Marsden PD, Lainson R 1990. The importance of rapid diagnoses of new cases of cutaneous leishmaniasis in pinpointing the sand fly vector. Trans R Soc Trop Med Hyg 84: 786.

Santos SO, Arias JR, de Paiva Hoffmann M, Furlan MB, Ferreira WF, Pereira C, Ferreira L 2003. The presence of Lutzomyia longipalpis in a focus of American visceral leishmaniasis where the only proven vector is Lutzomyia cruzi, Corumbá, Mato Grosso do Sul state. Rev Soc Bras Med Trop 36: 633-634. 
Sergent ED, Sergent ET, Parrot L, Donatieu A, Béguet M 1921. Transmission du clou de Biskra par le phlébotome (Phlebotomus papatasi Scop.). Comp Rend Acad Sci 173: 1030-1032.

Shaw J 2007. The leishmaniases - survival and expansion in a changing world. A mini- review. Mem Inst Oswaldo Cruz 102: 541-547.

Shaw J 2008. How climatic and environmental variations affect the eco-epidemiology of the leishmaniases and their control. III Workshop de Genética e Biologia Molecular de Insetos Vetores de Doenças Tropicais, 13 pp.

Shaw JJ, Ishikawa EAY, Lainson R, Braga RR, Silveira FT 1991. Cutaneous leishmaniasis of man due to Leishmania (Viannia) shawi Lainson, De Souza, Póvoa, Ishikawa \& Silveira in Pará state, Brazil. Ann Parasitol Hum Comp 66: 243-246.

Shaw JJ, Lainson R 1968. Leishmaniasis in Brazil: II. Observations on enzootic rodent leishmaniasis in the lower Amazon region The feeding habits of the vector Lutzomyia flaviscutellata in reference to man, rodents and other animals. Trans $R$ Soc Trop Med Hyg 62: 396-405.

Shaw JJ, Lainson R, Ryan L, Braga RR, Me-Mahon-Pratt D, David JR 1987. Leishmaniasis in Brazil. XXII. The identification of Leishmania braziliensis braziliensis in wild-caught neotropical sand flies using monoclonal antibodies. Trans $R$ Soc Trop Med Hyg 81: 69-72.

Shaw JJ, Lainson R, Ward RD 1972. Leishmaniasis in Brazil. VII. Further observations on the feeding habitats of Lutzomyia flaviscutellata (Mangabeira) with particular reference to its biting habits at different heights. Trans R Soc Trop Med Hyg 66: 718-723.

Sherlock I, Carneiro M 1962. Algumas fêmeas de Phlebotomus do Brasil (Diptera: Psychodidae). Mem Inst Oswaldo Cruz 60: 423-435.

Silva AM, de Camargo NJ, dos Santos DR, Massafera R, Ferreira AC, Postai C, Cristóvão EC, Konolsaisen JF, Bisetto A Jr, Perinazo R, Teodoro U, Galati EA 2008. Diversity, distribution and abundance of sand flies (Diptera: Psychodidae) in Paraná state, Southern Brazil. Neotrop Entomol 37: 209-225.

Silva DF, Vasconcelos SD 2005. Phlebotomine sand flies in fragments of rain forest in Recife, Pernambuco state. Rev Soc Bras Med Trop 38: 264-266.

Silva OS, Grunewald J 1999. Natural haematophagy of male Lutzomyia sand flies (Diptera: Psychodidae). Med Vet Entomol 13: 465-466.

Silveira FT, Ishikawa EA, de Souza AA, Lainson R 2002. An outbreak of cutaneous leishmaniasis among soldiers in Belém, Pará state, Brazil, caused by Leishmania (Viannia) lindenbergi n.sp. A new leishmanial parasite of man in the Amazon Region. Parasite 9: 43-50.

Silveira FT, Lainson R, Shaw JJ, Braga RR, Ishikawa EE, Souza AA 1991a. Cutaneous leishmaniasis in Amazonian: isolation of Leishmania (Viannia) lainsoni from the rodent Agouti paca (Rodentia: Dasyproctidae) in the state of Pará, Brazil. Rev Inst Med Trop Sao Paulo 33: 18-22.

Silveira FT, Shaw JJ, Braga RR, Ishikawa E 1987. Dermal leishmaniasis in the Amazon Region of Brazil: Leishmania (Viannia) lainsoni sp.n., a new parasite from the state of Pará. Mem Inst Oswaldo Cruz 82: 289-292.

Silveira FT, Souza AA, Lainson R, Shaw JJ, Braga RR, Ishikawa EE 1991b. Cutaneous leishmaniasis in the Amazon Region: natural infection of the sand fly Lutzomyia ubiquitalis (Psychodidae: Phlebotominae) by Leishmania (Viannia) lainsoni in Pará state, Brazil. Mem Inst Oswaldo Cruz 86: 127-130.

Souza A, Ishikawa E, Braga R, Silveira F, Lainson R, Shaw J 1996.
Psychodopygus complexus, a new vector of Leishmania braziliensis to humans in Pará state, Brazil. Trans $R$ Soc Trop Med Hyg 90: 112-113.

Souza CM, Pessanha JE, Barata RA, Monteiro EM, Costa DC, Dias ES 2004. Study on phlebotomine sand fly (Diptera: Psychodidae) fauna in Belo Horizonte, state of Minas Gerais, Brazil. Mem Inst Oswaldo Cruz 99: 795-803.

Souza MB, Cardoso PG, Sanavria A, Marzochi MCA, de Carvalho RW, Ribeiro PC, Ponte CS, Meira AM, Meródio JC 2003. Fauna flebotomínica do município de Bom Jardim, Região Serrana do estado do Rio de Janeiro, Brasil. Rev Bras Parasitol Vet 12: 150-153.

Souza NA, Andrade-Coelho CA, Peixoto AA, Rangel EF 2005. Nocturnal activity rhythms of Lutzomyia intermedia and Lutzomyia whitmani (Diptera: Psychodidae) in a transmission area of American cutaneous leishmaniasis in Rio de Janeiro state, Brazil. J Med Entomol 42: 986-992.

Souza NA, Andrade-Coelho CA, Vilela ML, Peixoto AA, Rangel EF 2002. Seasonality of Lutzomyia intermedia and Lutzomyia whitmani (Diptera: Psychodidae: Phlebotominae), occurring sympatrically in area of cutaneous leishmaniasis in the state of Rio de Janeiro, Brazil. Mem Inst Oswaldo Cruz 97: 759-765.

Souza NA, Vilela ML, Andrade-Coelho CA, Rangel EF 2001. The Phlebotominae sand fly (Diptera: Psychodidae) fauna of two Atlantic Rain Forest Reserves in the state of Rio de Janeiro, Brazil. Mem Inst Oswaldo Cruz 96: 319-324.

Souza-Rocha L, Falqueto A, dos Santos CB, Grimaldi G Jr, Cupolillo E 2007. Genetic structure of Lutzomyia (Nyssomyia) intermedia population from two ecologic regions in Brazil where transmission of Leishmania (Viannia) braziliensis reflects distinct ecoepidemiologic features. Am J Trop Med Hyg 76: 559-565.

Teodoro U, Salvia Filho VL, de Lima EM, Spinosa RP, Barbosa OC, Ferreira MEMC, Verzignassi TG 1993. Flebotomíneos em áreas de transmissão de leishmaniose na região norte do estado do Paraná - Brasil: variação sazonal e atividade noturna. Rev Saude Publica 27: 190-194.

Teodoro U, Silveira TG, dos Santos DR, dos Santos ES, dos Santos AR, de Oliveira O, Kuhl JB, Alberton D 2003. Influence of rearrangement and cleaning of the peridomiciliary area and building disinsectization on sand fly population density in the municipality of Doutor Camargo, Paraná state, Brazil. Cad Saude Publica 19: 1801-1813.

Tojal AC, Cupolillo E, Volpini AC, Almeida R, Romero GA 2006. Species diversity causing human cutaneous leishmaniasis in Rio Branco, state of Acre, Brazil. Trop Med Int Health 11: 1388-1398.

Tolezano JE, Marcoris SAG, Diniz JMP 1980. Modificação na epidemiologia da leishmaniose tegumentar no Vale do Ribeira, estado de São Paulo, Brasil. Rev Inst Adolfo Lutz 40: 49-54.

Vexenat JA, Barretto AC, Rosa AC 1986. Infecção experimental de Lutzomyia whitmani em cães infectados com Leishmania braziliensis braziliensis. Mem Inst Oswaldo Cruz 81: 125-126.

Vilela ML, Azevedo ACR, Afonso MMS, Silva DM, Rangel EF 2006. Estudos dos vetores das leishmanioses na área de influência do Aproveitamento Hidroelétrico Peixe Angical, estado de Tocantins. XLII Congresso da Sociedade Brasileira de Medicina Tropical. Rev Soc Bras Med Trop 39 (Suppl. I): 76.

Vilela ML, Azevedo ACR, Costa SM, Costa WA, Silva DM, Grajauskas AM, Moreira-de-Carvalho B, Paes LRDNB, Kozlowsky D, Rangel EF 2008. Sand fly survey in the influence área of Peixe Angical Hydroelectric Plant, state of Tocantins, Brazil. 6th International Symposium on Phlebotomine Sandflies, Lima, 95 pp.

Vilela ML, Azevedo ACR, Motta-Silva D, Costa WA, Rangel EF 2007. Estudos dos vetores das leishmanioses em áreas de in- 
fluência do Aproveitamento Hidroelétrico Peixe Angical, estado de Tocantins. XLIII Congresso da Sociedade Brasileira de Medicina Tropical. Rev Soc Bras Med Trop 40 (Suppl. I): 127.

Ward RD, Fraiha H 1977. Lutzomyia umbratilis, a new species of sand fly from Brazil (Diptera: Psychodidae). J Med Entomol 14: 313-317.

Ward RD, Lainson R, Shaw JJ 1973a. Further evidence of the role of Lutzomyia flaviscutellata (Mangabeira) as the vector of Leishmania mexicana amazonensis in Brazil. Trans $R$ Soc Trop Med Hyg 67: 608-609.

Ward RD, Lainson R, Shaw JJ 1977. Experimental transmissions of Leishmania mexicana amazonesnis Lainson \& Shaw, between hamsters by the bite of Lutzomyia flaviscutellata (Mangabeira). Trans R Soc Trop Med Hyg 71: 265-266.

Ward RD, Shaw JJ, Lainson R, Fraiha H 1973b. Leishmaniasis in Brazil. VIII. Observations on the phlebotomine fauna of an area highly endemic for cutaneous leishmaniasis in the Serra dos Carajás, Pará state. Trans $R$ Soc Trop Med Hyg 67: 174-183.

Wijers DJB, Linger R 1966. Man-biting sand flies in Surinam (Dutch Guiana): Phlebotomus anduzei as a possible vector of Leishmania braziliensis. Ann Trop Med Parasitol 60: 501-508.

Wilkes TJ, Ready PD, Lainson R, Killick-Kendrick R 1984. Biting periodicities of nulliparous and parous females of Psychodopygus wellcomei. Trans R Soc Trop Med Hyg 78: 846-847.

Ximenes MF, Castellon EG, de Souza MF, Freitas RA, Pearson RD, Wilson ME, Jerônimo SM 2000. Distribution of phlebotominae sand flies (Diptera: Psychodidae) in the state of Rio Grande do Norte, Brazil. J Med Entomol 37: 162-169.

Young DC, Duncan NA 1994. Guide to the identification and geographic distribution of Lutzomyia sand flies in México, the West Indies, Central and South America (Diptera: Psychodidae). Mem Ann Entomol Institut 54: 1-881. 